\title{
AMCoR
}

Asahikawa Medical College Repository http://amcor. asahikawa-med. ac. jp/

Journal of Hypertension (2008) 26(5):902-913.

Association of TNFRSF4 gene polymorphisms with essential hypertension.

Mashimo Y, Suzuki Y, Hatori K, Tabara Y, Miki T, Tokunaga K, Katsuya T, Ogihara T, Yamada M, Takahashi N, Makita Y, Nakayama T, Soma M, Hirawa N, Umemura S, Ohkubo T, Imai Y, Hata A. 


\section{Association of TNFRSF4 gene polymorphisms with essential hypertension}

Short title: TNFRSF4 gene and essential hypertension

Yoichi Mashimo $^{\mathrm{a}}$, Yoichi Suzuki ${ }^{\mathrm{a}}$, Kazuko Hatori ${ }^{\mathrm{a}}$, Yasuharu Tabara ${ }^{\mathrm{b}}$, Tetsuro Miki ${ }^{\mathrm{c}}$, Katsushi Tokunaga $^{\mathrm{d}}$, Tomohiro Katsuya ${ }^{\mathrm{e}}$, Toshio Ogihara ${ }^{\mathrm{e}}$, Michiko Yamada ${ }^{\mathrm{f}}$,

Norio Takahashi $^{\mathrm{g}}$, Yoshio Makita ${ }^{\mathrm{h}}$, Tomohiro Nakayama ${ }^{\mathrm{i}}$, Masayoshi Soma ${ }^{\mathrm{j}}$,

Nobuhito Hirawa $^{\mathrm{k}}$, Satoshi Umemura ${ }^{\mathrm{k}}$, Takayoshi Ohkubo ${ }^{1}$, Yutaka Imai ${ }^{\mathrm{m}}$, Akira Hata, ${ }^{\mathrm{a},{ }^{*}}$

${ }^{a}$ Department of Public Health, Graduate School of Medicine, Chiba University, Chiba, Japan; Departments of ${ }^{\mathrm{b}}$ Medical Genomics and ${ }^{\mathrm{c}}$ Geriatric Medicine, School of Medicine, Ehime University, Ehime, Japan; ${ }^{\mathrm{d}}$ Department of Human Genetics, Graduate School of Medicine, University of Tokyo, Tokyo, Japan; ${ }^{e}$ Department of Geriatric Medicine, Graduate School of Medicine, Osaka University, Osaka, Japan; Departments of ${ }^{\mathrm{f}}$ Clinical Studies and ${ }^{\mathrm{g}}$ Genetics, Radiation Effects Research Foundation, Hiroshima, Japan; ${ }^{\mathrm{h}}$ Department of Pediatrics, Asahikawa Medical College, Asahikawa, Japan; Divisions of ${ }^{\mathrm{i}}$ Molecular Diagnostics, Advanced Medical Research Center and ${ }^{\mathrm{j}}$ Nephrology and Endocrinology, Department of Medicine, Nihon University School of Medicine, Tokyo, Japan; ${ }^{k}$ Second Department of Internal Medicine, Graduate School of Medicine, Yokohama City University, Kanagawa,

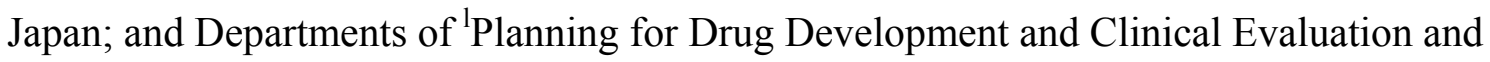
${ }^{\mathrm{m}}$ Clinical Pharmacology and Therapeutics, Graduate School of Pharmaceutical Sciences and Medicine, Tohoku University, Sendai, Japan.

*Correspondence to Akira Hata M.D., Ph.D., Department of Public Health, Graduate School of Medicine, Chiba University, 1-8-1 Inohana, Chuo-ku, Chiba 260-8670, Japan. 
Tel: +81 43 2262067; Fax: +81 43 2262070; e-mail: ahata@faculty.chiba-u.jp

\section{Sources of funding}

This work was supported by Grants-in-Aid from the Ministry of Education, Culture, Sports, Science and Technology, Japan.

\section{Conflicts of interest}

None

\section{Word count}

7228 words

\section{Abbreviations}

95\% CI, 95\% confidence interval; Agt, mouse angiotensinogen gene; ANOVA, analysis of variance; APC, antigen-presenting cell; CRP, C-reactive protein; DBP, diastolic blood pressure; EH, essential hypertension; HT, hypertensive; LD, linkage disequilibrium; MI, myocardial infarction; NT, normotensive; OR, odds ratio; PCR, polymerase chain reaction; SBP, systolic blood pressure; SD, standard deviation; SNP, single nucleotide polymorphism; TaqMan-ASA, TaqMan allele-specific amplification; TNFRSF4 (OX40), tumor necrosis factor receptor superfamily, member 4; TNFSF4 (OX40L), tumor necrosis factor (ligand) superfamily, member 4; UTR, untranslated region. 


\section{Abstract}

Essential hypertension is a complex disorder that results from the interaction of a number of susceptibility genes and environmental factors. The TNFRSF4 (tumor necrosis factor receptor superfamily, member 4) gene was one of the genes that showed altered renal expression in long-term salt loading in mice. Moreover, association of the TNFRSF4 and TNFSF4 (tumor necrosis factor (ligand) superfamily, member 4) genes with myocardial infarction was recently reported. Since essential hypertension is a well-known risk factor for myocardial infarction, we hypothesized that TNFRSF4 could be a susceptibility gene for essential hypertension. We performed a case-control study of TNFRSF4 in two independent populations. Extensive investigation of SNPs of the entire gene suggested that it resided in one linkage disequilibrium block, and 4 SNPs in the $5^{\prime}$ flanking region sufficiently represented major haplotypes. In the combined population, the frequency of the most frequent haplotype, C-C-A-A, was significantly lower $\left(P=8.07 \times 10^{-5}\right)$ and that of the second most frequent haplotype, C-T-G-A, was significantly higher $\left(P=6.07 \times 10^{-4}\right)$ in hypertensive subjects than in control subjects. This difference was observed only in female patients. The C-T-G-A haplotype showed a lower promoter activity than other haplotypes, suggesting a

relationship with disease susceptibility. Our results suggest that TNFRSF4 is a female-specific susceptible gene for essential hypertension. 


\section{Condensed Abstract}

We selected the TNFRSF4 (tumor necrosis factor receptor superfamily, member 4) gene as a candidate gene for essential hypertension susceptibility and performed a case-control study of the gene in two independent populations. Haplotype analysis using 4 SNPs in the 5' flanking region of the gene revealed that the frequency of the most frequent haplotype was significantly lower and that of the second most frequent haplotype was significantly higher than controls, in female patients only. Furthermore, the second most frequent haplotype showed a lower promoter activity than other haplotypes. Our results suggest that TNFRSF4 is a female-specific susceptible gene for essential hypertension.

\section{Key Words}

hypertension, essential; association studies; SNPs; haplotype; TNFRSF4 gene 


\section{Introduction}

Hypertension affects more than $25 \%$ of the adult population worldwide [1]. Essential hypertension (EH) accounts for more than $90 \%$ of hypertension cases and is a multifactorial disorder resulting from the interaction of a number of susceptibility genes and environmental factors. It is estimated that the genetic contribution to blood pressure variation ranges from 30 to $50 \%$ [2]. Identification of susceptibility genes for hypertension would provide a clue to the pathophysiology of the disease.

There are several approaches for genetically dissecting $\mathrm{EH}$; candidate-gene linkage studies, genome-scanning linkage studies, candidate-gene association studies, genetic studies in animal models, and gene expression profiling in animal models [3]. Each approach has its own strengths and weaknesses, and some argue integration of the approaches is a more efficient way forward [4]. The Millennium Genome Project for Hypertension in Japan has adopted the candidate-gene association strategy because of its relatively higher statistical power and convenience of collecting samples [5]. Candidate genes are selected based on the accumulation of experimental evidence (expression profiling in animal models) and information in the literature. As a first step in this project, we performed DNA microarray experiments in mice to screen genes whose renal expression was changed by long-term salt loading, because genes that showed salt sensitivity were considered to be candidate genes for EH. The results showed that more than 300 genes were either downregulated or upregulated. For the genetic association study, from these 300 genes we nominated 121 that had been reported in the literature as candidate genes. To date, 70 genes have been screened, 10 of which showed significant association with EH on haplotype-based analysis. Three of these 10 genes were positive in both the expression profiling and genetic association studies. The tumor necrosis factor receptor superfamily, member 4 (TNFRSF4) gene was one of the three. 
TNFRSF4 (OX40) is a member of the tumor-necrosis factor receptor (TNFR) superfamily, and is primarily expressed as a transmembrane protein on activated $\mathrm{CD} 4^{+} \mathrm{T}$ cells after antigen recognition [6-9]. Tumor necrosis factor (ligand) superfamily, member 4 (TNFSF4, also called OX40L) [10], the ligand for TNFRSF4 on activated CD4 ${ }^{+} \mathrm{T}$ cells, is expressed on antigen-presenting cells (APCs) including activated B cells, macrophages and dendritic cells, as well as on endothelial cells and some activated T cells [11-14]. The TNFRSF4-TNFSF4 interaction between $\mathrm{T}$ cell and APC contributes to proinflammatory $\mathrm{T}$ cell function. In particular, TNFRSF4-TNFSF4 interactions are crucial for the generation of memory $\mathrm{CD}^{+} \mathrm{T}$ cells by promoting the survival of effector $\mathrm{T}$ cells [15-18]. Thus, it is suggested that the TNFRSF4-TNFSF4 pathway is involved in inflammation and immune response.

$\mathrm{T}$ lymphocyte activation involving several receptor-ligand pairs such as TNFRSF4-TNFSF4 is suggested to promote atherosclerosis $[12,19,20]$, which is now considered to be an inflammatory disease [21]. Recently, TNFSF4 was identified as a susceptibility gene for atherosclerosis and a genetic variation in TNFSF4 was reported to be associated with myocardial infarction (MI) and severity of coronary artery disease [22]. Genetic variation in TNFRSF4 was also shown to be associated with MI [23]. These reports suggested that the TNFRSF4-TNFSF4 pathway plays an important role in the pathogenesis of atherosclerosis and MI in humans. It is generally believed that hypertension is one of the major risk factors for atherosclerosis and MI [24]; however, MI and hypertension often coexist, as seen in the SHEEP study cohort in which MI patients were significantly associated with hypertension [25]. Thus, the association between MI and TNFRSF4/TNFSF4 in human subjects may be due to not only atherogenesis but also hypertension itself. We hypothesized that TNFRSF4 and/or TNFSF4 were potential candidate genes for EH.

The aim of the present study is to investigate the association between genetic variations of the TNFRSF4 gene and EH in the Japanese population. We performed a case-control study 
using two independent populations of Japanese patients with EH. 


\section{Methods}

\section{Study Subjects}

Initial screening of candidate genes involved 1035 subjects with EH (762 males and 273 females) and 1058 age-matched controls (792 males and 266 females) who were recruited through the study group of the Millennium Genome Project for Hypertension [5]. Six medical institutes took part in the collaborative study and recruited subjects in Japan. Recruitment procedures, case-control criteria, and clinical characteristics are described in detail elsewhere $[5]$.

The clinical characteristics of the subjects included in this study for TNFRSF4 gene analyses are shown in (Table 1) and (Table 2). Subjects in population 1 were a part of the population recruited through the study group of the Millennium Genome Project for Hypertension [5]. Subjects in population 2 were recruited from Ohasama, a cohort in a rural community of northern Japan [26].

Each subject was assigned to one of the blood pressure diagnostic categories defined by the criteria of the $1999 \mathrm{WHO} / \mathrm{ISH}$ guidelines for the management of hypertension [27]. Hypertensive (HT) subjects had systolic blood pressure (SBP) $\geq 140 \mathrm{mmHg}$ or diastolic blood pressure $(\mathrm{DBP}) \geq 90 \mathrm{mmHg}$ or were patients currently taking chronic antihypertensive medication. Normotensive (NT) subjects had SBP/DBP $<140 / 90 \mathrm{mmHg}$, and had never been treated with antihypertensive medication. Informed consent was obtained from each individual as per the protocol approved by each institution's ethics committee.

\section{DNA microarray experiments in mice}

In DNA microarray experiments, we used two lines of mice having different numbers of the functional mouse angiotensinogen gene (Agt) [28, 29], kindly donated by Professor Oliver 
Smithies (Department of Pathology, University of North Carolina). To observe distinct effects by long-term salt loading, Agt 2/2 mice (with four wild-type copies of the Agt gene) were fed a high-salt diet containing $8 \% \mathrm{NaCl}$ for six months, while Agt 0/1 mice (with one wild-type copy of the Agt gene) were fed a low-salt diet containing $0.3 \% \mathrm{NaCl}$. Total RNA was isolated from the kidneys of mice and differences in gene expression were examined using mouse cDNA microarray (Incyte Genomics, Inc.), which contains 9222 mouse cDNA clones.

\section{Screening of candidate genes}

We selected a total of 121 candidate genes (Supplemental Table 1) based on the following criteria: (i) were genes reported as candidates in the literature or with functions relevant to the blood pressure regulation, and (ii) were human homolog of genes in which renal expression was changed by long-term salt loading in mice. For an initial screening of these candidate genes, some of the available single nucleotide polymorphisms (SNPs) per gene were selected from the Japanese SNP database (http://snp.ims.u-tokyo.ac.jp/) or dbSNP database (http://www.ncbi.nlm.nih.gov/SNP/) and were genotyped in 1035 patients and 1058 controls using the PCR-SSP-FCS method [30]. Haplotype-based association analyses were performed using SNPAlyze v4.1 Pro software (DYNACOM, Mobara, Japan) based on an expectation/maximization (EM) algorithm. $P$ values for overall distribution of haplotypes were calculated by permutation test at 1000 iterations. $P$ values less than 0.05 were considered statistically significant.

\section{Screening for polymorphisms in TNFRSF4}

To identify genetic variants of the human TNFRSF4 gene, we sequenced all 7 exons, the adjacent intronic sequence, $4 \mathrm{~kb}$ of the 5 ' flanking region and $1.5 \mathrm{~kb}$ of the 3 ' flanking region in 32 control subjects. Nineteen primer sets were designed on the basis of the TNFRSF4 
genomic and mRNA sequences from the GenBank database (accession numbers NT_004350.18 and NM_003327, respectively). All polymerase chain reaction (PCR) products were sequenced using the BigDye Terminator v3.1 Cycle Sequencing kit and an ABI PRIZM 3100 Genetic Analyzer (Applied Biosystems, Foster City, CA). The sequences were analyzed and polymorphisms identified using the Genetyx program (Genetyx Corp., Tokyo, Japan).

\section{Genotyping of polymorphisms in TNFRSF4}

Genotyping of four SNPs in the TNFRSF4 gene (P1: $-3948 \mathrm{C}>\mathrm{T}, \mathrm{P} 2$ : $-3606 \mathrm{C}>\mathrm{T}$, P8: $-1725 \mathrm{~A}>\mathrm{G}$ and $\mathrm{P} 12$ : $-530 \mathrm{~A}>\mathrm{G}$ ) was performed using either the $\operatorname{TaqMan}^{\mathrm{TM}}$ allele-specific amplification (TaqMan-ASA) method [31] or the Custom TaqMan ${ }^{\mathrm{TM}}$ Genomic Assays kit (Applied Biosystems). In the TaqMan-ASA method, specific primers were designed on the basis of the TNFRSF4 genomic sequence from the GenBank database (accession number NT_004350.18). The primer sequences are shown in (Table 3). The PCR mixture for the TaqMan-ASA method contained $5 \mu$ of $2 \times \operatorname{TaqMan}^{\mathrm{TM}}$ Universal Mix (Applied Biosystems), $0.4 \mu \mathrm{mol} / \mathrm{L}$ of each PCR primer, $0.12 \mu \mathrm{mol} / \mathrm{L}$ of TaqMan probe, and $5 \mathrm{ng}$ of template DNA in a final volume of $10 \mu \mathrm{l}$. The samples were analyzed with an ABI PRIZM 7000 Sequence Detection system (Applied Biosystems). The thermoprofiles were $50^{\circ} \mathrm{C}$ for $2 \mathrm{~min}, 95^{\circ} \mathrm{C}$ for $10 \mathrm{~min}$, followed by 40 cycles of $95^{\circ} \mathrm{C}$ for $15 \mathrm{sec}$ and $60^{\circ} \mathrm{C}$ for $1 \mathrm{~min}$.

\section{Luciferase assay}

TNFRSF4 reporter constructs of 3970 bp (nt -3968 to +2$)$ were created by means of PCR amplification of genomic DNA from homozygous subjects who had alternative haplotypes with the of following primers: forward, 5'-GGGGTACCGTGCCACATGGCTGGAATTTAC-3' (including KpnI site) and reverse, 
5'-TCTAGCTAGCGTCTCTGCTGTCGCCAGAGTC-3' (including NheI site). Amplicons of three haplotypes (Pr-H1, Pr-H2 and Pr-H5) were cloned into the pGL4.10[luc2] vector (Promega, Madison, WI). Promoter constructs that contained one polymorphic change (Pr-P2-T, Pr-P3-T, Pr-P4-del, Pr-P6-G, Pr-P8-G, Pr-P9-G, Pr-P10-T, and Pr-P11-G) were created by site-directed mutagenesis carried out in the Pr-H1 plasmid using the GeneEditor ${ }^{\mathrm{TM}}$ in vitro site-directed mutagenesis system (Promega). All constructs were verified by sequencing. COS-7 cells (monkey kidney, SV40 T antigen-transformed) were cultured in Dulbecco's modified Eagle's medium supplemented with $10 \%$ fetal bovine serum and antibiotics. HEK293 cells (human embryonic kidney) were cultured in minimum essential medium supplemented with $2 \mathrm{mmol} / \mathrm{L}$ L-glutamine, $1 \%$ non-essential amino acids, $10 \%$ fetal bovine serum and antibiotics. Cells in 12-well plates at 50-70\% confluence were transfected with $500 \mathrm{ng}$ of each construct and $10 \mathrm{ng}$ of pGL4.74[hRluc/TK] Renilla luciferase vector (Promega) as an internal control for transfection efficiency, using $1.5 \mu$ of FuGENE 6 transfection reagent (Roche Diagnostics, Basel, Switzerland). After 24 hours of transfection, the cells were harvested, and firefly and Renilla luciferase activities were measured using the Dual-Luciferase Reporter Assay System and a TD-20/20 luminometer (Promega). Each experiment was repeated five or six times, and each sample was studied in triplicate.

\section{Statistical analysis}

Haploview version 3.32 (http://www.broad.mit.edu/mpg/haploview/index.php) was used to analyze and visualize the linkage disequilibrium (LD) and haplotypic patterns. Hardy-Weinberg equilibrium was assessed by $\chi^{2}$ analysis. Overall distributions of the genotypes or alleles were analyzed by $\chi^{2}$ analysis using $2 \times 3$ or $2 \times 2$ contingency tables between NT controls and HT patients. Haplotype frequencies were estimated using SNPAlyze v4.1 Pro software. The distributions of each haplotype between NT controls and HT patients 
were calculated both by $\chi^{2}$ tests of one haplotype against the others (haplotype-wise test) and by permutation tests with 1000 iterations using SNPAlyze software. We calculated odds ratios (ORs) with 95\% confidence intervals (CIs) using logistic regression analyses with or without clinical covariates (age, body mass index, total cholesterol, high-density lipoprotein cholesterol, and triglyceride). To estimate the contribution of the gene to the total variance of blood pressure, the variance component procedure with the analysis of variance (ANOVA) type III variance estimates was used. Comparisons in reporter assays were performed using Student's $t$-test or ANOVA. All statistical analyses were performed with SPSS software (SPSS Japan Inc, Tokyo, Japan) unless otherwise stated. $P$ values less than 0.05 were considered statistically significant. 


\section{Results}

\section{DNA microarray experiments in mice}

We used cDNA microarray analyses to compare the expression profiles of 9222 genes in the kidneys of Agt 2/2 mice (with four wild-type copies of the Agt gene) with a high-salt diet vs. those of Agt 0/1 mice (with one wild-type copy of the Agt gene) with a low-salt diet. Differential expression values greater than 1.3 based on internal quality control data are summarized in (Supplemental Table 2) and (Supplemental Table 3). We found that 119 genes were downregulated in the kidneys of Agt 2/2 mice by 1.3- to 3.1-fold compared with Agt 0/1 mice, and 192 genes were upregulated by 1.3- to 1.9-fold. Murine TNFRSF4 gene (Tnfrsf4) was the gene downregulated 1.3 fold.

\section{Screening of candidate genes by haplotype association study}

We selected a total of 121 candidate genes (Supplemental Table 1) based on the following criteria: (i) were genes reported as candidates in the literature or with possible involvement of blood pressure regulation, and (ii) were human homolog of genes in which renal expression was changed by long-term salt loading in mice. We excluded genes whose genotype data were not available due to the following reasons: no SNP data was available in the databases; minor allele frequencies of SNPs in Japanese were too low $(<5 \%)$; or the genotyping of some SNPs was difficult. So far, 191 SNPs in 70 genes have been successfully genotyped for genetic association tests, and the genotyping of only a single SNP was completed in 8 genes. A haplotype-based association test was performed in 62 genes and a single SNP association study in 8 genes. $P$ values for difference in overall distribution of the haplotype or genotype frequencies between NT and HT in total (male + female), male, and female subjects are shown in (Supplemental Table 4). Significant $P$ values were observed for 10 genes; 
Aquaporin-2 (AQP2), Estrogen receptor 2 (ESR2), Glycogen synthase 1 (GYS1), Kallikrein 1 (KLK1), Nephrin (NPHN), Solute carrier family 1 (glial high affinity glutamate transporter), member 2 (SLC1A2), Solute carrier family 9 (sodium/hydrogen exchanger), isoform 3 (SLC9A3), Steroidogenic acute regulatory protein (STAR), Syntaxin binding protein 1 (STXBP1) and TNFRSF4. Three genes (STAR, STXBP1, and TNFRSF4) are the human homologs to the mouse genes that showed changes in renal expression in the salt-loading experiment. The $P$ value for overall distribution of the haplotype of TNFRSF4 was significant only in female subjects.

\section{Identification of polymorphisms in TNFRSF4}

We searched for polymorphisms in the TNFRSF4 gene, including $4 \mathrm{~kb}$ of the 5 ' flanking region and $1.5 \mathrm{~kb}$ of the 3 ' flanking region. By direct sequencing in 32 Japanese individuals, a total of 44 polymorphisms were identified; 20 in the 5 ' flanking region, 4 in exons, 7 in introns, and 13 in the 3 ' flanking region. Of those, 27 polymorphisms (P1-P27) with minor allele frequencies (MAF) $\geq 5 \%$ (in 32 DNA samples) are presented in (Table 4). A graphical overview of the structure of the human TNFRSF4 gene showing the location of the 27 polymorphisms identified in this study is shown in (Fig. 1). Pair-wise LD measuring $r^{2}$ between polymorphisms and defined haplotype block structures in this region was evaluated using the solid spine of LD method in Haploview (Fig. 1). Three haplotype blocks (blocks 1, 2 and 3) were defined in the TNFRSF4 gene region with this method. Blocks 1 and 2 appear to be separated because P8 showed low LD to other polymorphisms and blocks 2 and 3 were separated by P22 for the same reason. However, strong LDs were observed among certain blocks, such as between P4 and P27 $\left(r^{2}=0.91\right)$. In addition, multiallelic D' values between these blocks were high $(0.86$, between blocks 1 and 2; 1.0, between blocks 2 and 3$)$. Thus, we decided to handle an entire gene region as one block, which could be analyzed by tag SNPs 
from the entire region. Four SNPs in the 5' flanking region $(\mathrm{P} 1:-3948 \mathrm{C}>\mathrm{T}, \mathrm{P} 2 \mathrm{:}-3606 \mathrm{C}>\mathrm{T}$, P8: $-1725 \mathrm{~A}>\mathrm{G}$ and P12: $-530 \mathrm{~A}>\mathrm{G}$ ) were employed for further analysis. The 4-SNP haplotypes constructed from these SNPs covered more than $85 \%$ of haplotype diversity of the entire TNFRSF4 gene when P22 was not included for analysis.

\section{Case-control study for TNFRSF4 polymorphisms}

The clinical characteristics of the normotensive (NT) and hypertensive (HT) subjects in population 1 are summarized in (Table 1). Difference in age between the NT and HT subjects was significant when males and females were jointly compared $(P=0.011)$, whereas it was not significant when males and females were separately compared.

In population 1, 4 SNPs (P1, P2, P8 and P12) were genotyped in 562 NT controls and 587 HT patients. All of these SNPs were in Hardy-Weinberg equilibrium in the NT group. (Table 5) shows the distribution of genotypic and allelic frequencies of the 4 SNPs in each group. The overall distribution of genotype and allele did not significantly differ between the HT and NT groups for total, male or female subjects. The $P$ value of $\chi^{2}$ test for the difference in the genotypic frequency of P8 between the male HT and NT groups was 0.044 , which was not significant after Bonferroni's correction (multiplied by 4).

We next analyzed the 4-SNP haplotype in population 1 (Table 6). Six common haplotypes (H1 to H6) covered approximately $99 \%$ of subjects in the HT and NT groups. The frequencies of each haplotype in males did not differ between the HT and NT groups. However, in females, the frequency of the major C-C-A-A haplotype (H1) of the HT subjects was significantly lower than that of the NT subjects $(P=0.031)$. Multiple logistic regression in females revealed that the association of the $\mathrm{H} 1 / \mathrm{H} 1$ diplotype with hypertension remained significant $(P=0.006)$ after adjustment for age, body mass index, total cholesterol, high-density lipoprotein cholesterol, and triglyceride. The OR of the H1/H1 diplotype against 
the others was 0.56 with a $95 \%$ CI of $0.37-0.85$. The frequency of the minor C-C-A-G haplotype (H5) of the HT subjects was significantly higher than that of the NT subjects $(P=$ $6.78 \times 10^{-5}$ ). H5 haplotype was significantly associated with hypertension in a dominant model $(P=0.004)$ after adjustment for the above factors. The OR of the H5/H5+H5/other diplotype against the others was 6.93 with a $95 \%$ CI of $1.88-25.5$.

To confirm an association of the 4-SNP haplotype with female EH, we genotyped 4 SNPs using the second case-control population (population 2) comprising 925 NT controls and 732 HT patients. (Table 2) presents the clinical features of the NT controls and HT patients in population 2. All genotype results of 4 SNPs in each group were consistent with Hardy-Weinberg equilibrium. (Table 7) shows the distribution of genotypic and allelic frequencies of 4 SNPs in each group of population 2. The overall distribution of genotype and allele of all 4 SNPs did not significantly differ between the HT and NT groups for total or male subjects. However, among women, significant differences were observed in the allelic frequencies of $\mathrm{P} 2(P=0.005)$ and the genotypic and allelic frequencies of $\mathrm{P} 8(P=0.005$ and 0.003, respectively) between the HT and NT subjects even after Bonferroni's correction (multiplied by 4). P2 was still significantly associated with hypertension in females in both a dominant $(P=0.007)$ and recessive model $(P=0.038)$ after adjustment for age, body mass index, total cholesterol, high-density lipoprotein cholesterol, and triglyceride. The OR of $\mathrm{T} / \mathrm{T}+\mathrm{C} / \mathrm{T}$ against $\mathrm{C} / \mathrm{C}$ (dominant model) was 1.22 with a $95 \% \mathrm{CI}$ of $1.05-1.40$, and the OR of $\mathrm{T} / \mathrm{T}$ against $\mathrm{C} / \mathrm{T}+\mathrm{C} / \mathrm{C}$ (recessive model) was 1.94 with a $95 \% \mathrm{CI}$ of $1.04-3.62$. P22 was also significantly associated with hypertension in females in both a dominant model $(P=0.011)$ and recessive model $(P=0.002)$ after adjustment for the above factors. The OR of $G / G+A / G$ against A/A (dominant model) was 1.20 with a $95 \%$ CI of $1.04-1.38$, and the OR of $\mathrm{G} / \mathrm{G}$ against $\mathrm{A} / \mathrm{G}+\mathrm{G} / \mathrm{G}$ (recessive model) was 1.49 with a $95 \%$ CI of $1.16-1.92$.

(Table 8) shows the frequency of 4-SNP haplotypes in population 2. Among females, the 
HT subjects showed a significantly lower frequency of H1 (C-C-A-A) $\left(P=8.48 \times 10^{-4}\right)$ and a significantly higher frequency of $\mathrm{H} 2(\mathrm{C}-\mathrm{T}-\mathrm{G}-\mathrm{A})\left(P=6.46 \times 10^{-4}\right)$ than the NT subjects, whereas in males no significant difference in frequencies of haplotypes between the HT and NT groups was observed. Multiple logistic regression in females revealed that the association of $\mathrm{H} 1$ haplotype with hypertension remained significant in both a dominant $(P=0.006)$ and recessive model $(P=0.005)$ after adjustment for age, body mass index, total cholesterol, high-density lipoprotein cholesterol, and triglyceride. The OR of the H1/H1+H1/other diplotype against the others (dominant model) was 0.52 with a $95 \% \mathrm{CI}$ of $0.32-0.83$, and the OR of the $\mathrm{H} 1 / \mathrm{H} 1$ diplotype against the others (recessive model) was 0.67 with a $95 \% \mathrm{CI}$ of 0.50-0.89. The $\mathrm{H} 2$ haplotype was also significantly associated with hypertension in females in a dominant model $(P=0.001)$ after adjustment for the above factors. The OR of the $\mathrm{H} 2 / \mathrm{H} 2+\mathrm{H} 2 /$ other diplotype against the others was 1.40 with a $95 \% \mathrm{CI}$ of $1.18-1.65$. In population 2, the frequency of H5 did not significantly differ between the HT and NT groups for females.

Although trends of frequency changes in the $\mathrm{H} 1$ and $\mathrm{H} 2$ haplotypes among women in the two independent populations were the same, the frequency of $\mathrm{H} 2$ showed a significant difference not in population 1 but in population 2. This discrepancy could have been caused by difference in the sample size. When we analyzed the differences in frequencies of each haplotype between the HT and NT groups in combined samples of the two populations (Table 9), female HT subjects showed a significantly lower frequency of H1 $\left(P=8.07 \times 10^{-5}\right)$ and a significantly higher frequency of $\mathrm{H} 2\left(P=6.07 \times 10^{-4}\right)$ than the NT subjects. The frequency of H5 of female HT subjects was still significantly higher than that of NT subjects $(P=$ 0.003). No significant difference in haplotype frequencies between male HT and NT groups was observed. 


\section{Variance component estimation of TNFRSF4}

The variance estimates of the TNFRSF4 diplotype and the residual in SBP of the control females of population 1 were 5.5 and 79.6, respectively. Therefore, the TNFRSF4 gene explains $6.5 \%$ of the variation of SBP in this group. The values in DBP were 2.8 and 52.1, respectively, with the gene contributing $5.2 \%$ of the variation.

\section{Transcriptional effects of polymorphisms in the promoter region}

To study transcriptional effects of the polymorphisms, we transfected COS-7 cells and HEK293 cells with promoter constructs containing the haplotypes in the TNFRSF4 gene (Pr-H1, Pr-H2 and Pr-H5). In COS-7 cells, promoter activity of the Pr-H2 construct was significantly lower than that of the Pr-H1 or Pr-H5 construct $(0.89$ for $\mathrm{Pr}-\mathrm{H} 2 / \mathrm{Pr}-\mathrm{H} 1, \mathrm{P}=$ 0.008 and 0.91 for Pr-H2/Pr-H5, $P=0.026$; Fig 2a). The same results were observed in HEK293 cells (0.92 for Pr-H2/Pr-H1, $P=0.001$ and 0.88 for Pr-H2/Pr-H5, $P=0.001$; Fig 2c). There was no significant difference in promoter activity between the Pr-H1 and Pr-H5 constructs in both cells. These results suggest that expression of TNFRSF4 mRNA in cells is lower in individuals who have the $\mathrm{H} 2$ haplotype than in cells from individuals who have other types of haplotypes. To clarify the responsible SNP(s) for the lower promoter activity of Pr-H2, we performed an additional assay using a series of promoter constructs that contained only one polymorphic change (Pr-P2-T, Pr-P3-T, Pr-P4-del, Pr-P6-G, Pr-P8-G, Pr-P9-G, Pr-P10-T, and Pr-P11-G). In COS-7 cells, promoter activities of Pr-P2-T, Pr-P6-G and Pr-P11-G were significantly lower than that of Pr-H1 (0.69 for Pr-P2-T/Pr-H1, $P<0.0001$, 0.90 for Pr-P6-G/Pr-H1, $P=0.016$ and 0.88 for Pr-P11-G/Pr-H1, $P=0.015$; Fig 2b). In HEK293 cells, as in COS-7 cells, Pr-P2-T showed significantly lower promoter activity when compared with Pr-H1 (0.71 for Pr-P2-T/Pr-H1, $P=0.0001$; Fig. 2d). The results of other constructs, however, were different: promoter activities of Pr-P8-G and Pr-P11-G were 
significantly higher than that of Pr-H1 (1.04 for Pr-P8-G/Pr-H1, $P=0.002$ and 1.10 for Pr-P11-G/Pr-H1, $P=0.003$; Fig 2d). Only Pr-P2-T showed consistent change in promoter activity in the two different cell lines. These results suggest that $\mathrm{P} 2$ had the largest impact on the decreased promoter activity of the $\mathrm{H} 2$ haplotype. 


\section{Discussion}

The significance of TNFRSF4 in the pathogenesis of female EH was indicated in two independent sets of populations. Haplotype analysis using 4 SNPs (P1: $-3948 \mathrm{C}>\mathrm{T}, \mathrm{P} 2$ : $-3606 \mathrm{C}>\mathrm{T}, \mathrm{P} 8:-1725 \mathrm{~A}>\mathrm{G}$ and $\mathrm{P} 12:-530 \mathrm{~A}>\mathrm{G}$ ) in the 5' upstream region showed that the frequency of H1 (C-C-A-A) was significantly low among female HT patients when compared with female NT controls in both population $1(P=0.031)$ and population $2\left(P=8.48 \times 10^{-4}\right)$. The frequency of H2 (C-G-T-A) of female HT patients was significantly higher than that of female NT controls in population $2\left(P=6.46 \times 10^{-4}\right)$, but not in population 1 . In the combined population, both significantly lower frequency of H1 $\left(P=8.07 \times 10^{-5}\right)$ and significantly higher frequency of $\mathrm{H} 2\left(P=6.07 \times 10^{-4}\right)$ were observed in female HT patients compared to female NT controls. No difference in haplotype frequencies between the HT and NT groups was observed in the male subjects of either the combined or separate populations. These results of association of the TNFRSF4 haplotype with hypertension suggested that the $\mathrm{H} 1$ haplotype is a protective allele and that the $\mathrm{H} 2$ haplotype is a high-risk allele for $\mathrm{EH}$ in women. The promoter activity of the $\mathrm{H} 2$ haplotype was significantly lower than that of the H1 and H5 (C-C-A-G) haplotypes. Furthermore, the Pr-P2-T construct showed lower promoter activity than other constructs. Allelic association of P2 (-3606C $>$ T, rs 12036216) with female HT patients was significant in population 2 and the combined population (data not shown), but not in population 1. These data suggested that P2 is the responsive SNP that modifies the risk for hypertension in females, although it is possible that unidentified variant(s) in linkage disequilibrium with this haplotype have function(s) that influence disease susceptibility. We also observed a significant difference of frequency in the H5 haplotype in the combined population $(P=0.003)$ and in population $1\left(P=6.78 \times 10^{-5}\right)$, but not in population 2. However, we could not find any transcriptional effect of H5 haplotype. 
The TNFRSF4-TNFSF4 interactions on $\mathrm{T}$ lymphocytes enhance proliferation and differentiation of the cells as well as generation and survival of memory $\mathrm{CD} 4^{+} \mathrm{T}$ cells in the process of inflammation and immune response [15-18]. Several inflammatory markers, such as soluble leukocyte adhesion molecules, cytokines, specific growth factors, heat shock proteins, CD40L, and C-reactive protein (CRP), were reported to increase in patients with $\mathrm{EH}$ [32-41]. Although the relationship between inflammation and hypertension has not been well established, a growing body of evidence indicates that vascular inflammation may be involved in both the initiation and development of hypertension [42-46]. Sesso et al. showed that elevated plasma CRP, a well-known marker of inflammation, was associated with the future development of hypertension in a dose-dependent manner [46]. Furthermore, hypertension has been suggested to trigger inflammation through the increased expression of several mediators, including leukocyte adhesion molecules, chemokines, specific growth factors, heat shock proteins, endothelin-1, and angiotensin [47-54]. Given our findings that variants of the TNFRSF4 gene, which might affect the inflammatory cascade, were associated with $\mathrm{EH}$ among women, it is likely that inflammation may play a role in initiation and/or development of hypertension.

Inflammatory process [21] and T lymphocyte activation $[12,19,20]$ are implicated to be involved in the pathogenesis of atherosclerosis. Thus alteration(s) in the TNFRSF4-TNFSF4 pathway could influence atherosclerosis formation. Indeed, Wang et al. found that polymorphisms of TNFSF4 are associated with myocardial infarction (MI) in women [22]. Furthermore, a polymorphism in TNFRSF4 was also reported to be associated with MI [23]. These studies strongly suggested that genes involved in the TNFRSF4-TNFSF4 pathway play a role in the pathogenesis of atherosclerosis and MI, particularly in women.

Our findings combined with those of the reports mentioned above suggested that genetic variations in the TNFRSF4-TNFSF4 pathway may be involved in the pathogenesis of both 
atherosclerosis and hypertension. So, which comes first, atherosclerosis or hypertension? Hypertension is one of the principal risk factors for atherosclerosis and MI [24], but the exact mechanism underlying the association is not fully understood. Although arterial stiffness, which is a predictor of atherosclerosis $[55,56]$, has been thought to be the result of hypertension rather than its cause, recent studies suggested that arterial stiffness is related to the development of hypertension $[57,58]$. These data indicated that the relationship between hypertension and arterial stiffness may be bidirectional [59]. Therefore, three different scenarios are possible to explain the results that genetic variations in the TNFRSF4-TNFSF4 pathway are associated with both hypertension and MI. First, inflammation may directly increase arterial stiffness and induce the development of an atherosclerotic lesion, which may lead to the development of hypertension. Second, inflammation may induce hypertension, which may result in increasing arterial stiffness and atherosclerosis. Third, inflammation may promote the development of hypertension and atherosclerosis by different pathways. Although it is not clear whether atherosclerosis is a cause of hypertension, our findings and previous studies indicate that the inflammation may be an important part of the link between hypertension and atherosclerosis and cardiovascular events, such as MI.

TNFSF4 is also a potential candidate for a susceptibility gene involved in the pathogenesis of female $\mathrm{EH}$. We therefore examined the putative association between polymorphisms in the TNFSF4 gene and hypertension in population 1 . The allele frequencies of 4 SNPs (rs1234315, rs3850641, rs1234313, and rs3861950) and its haplotype did not significantly differ between the HT group and the NT group for females (data not shown). In contrast to the case of MI where susceptibility was affected by variations of both TNFRSF4 and TNFSF4, susceptibility for hypertension may be affected only by TNFRSF4, though more extensive studies are required before we conclude an association of TNFSF4 with hypertension. 
In the present study, we found that variations of TNFRSF4 affected hypertension susceptibility only in females. This is an interesting similarity to female-specific MI susceptibility exerted by TNFSF4 and TNFRSF4. Some case-control studies have identified gene variants associated with gender-specific susceptibility to EH [5, 60, 61]. Recently, Nakayama et al.[5] reported that an SNP in the 5'-untranslated region of the follicle-stimulating hormone receptor $(F S H R)$ gene, in which mutations were reported to cause hereditary hypergonadotropic ovarian failure [62], was associated with EH in women and affected the levels of transcriptional activity. In this study the functional mutation of the gene was clearly identified in patients with EH in a gender-specific manner. Currently, the reason for female-specific association of TNFRSF4 with EH is an open question. One possibility is the involvement of the female sex hormone, estrogen. After menopause, females' risk for inflammatory cardiovascular diseases such as atherosclerosis and coronary heart disease increases, suggesting that estrogens modulate the initiation and progress of inflammation [63-65]. Recently, Xing et al. [66] suggested that estrogen may exert anti-inflammatory effects by inhibiting tumor necrosis factor- $\alpha$-mediated chemokine production in vascular smooth muscle cells. However, estrogen is also known to increase CRP, which is an inflammatory marker [63]. These findings indicate that estrogen may modulate production of several proinflammatory molecules in distinct pathways. It is possible that TNFRSF4 and estrogen cross-talk in inflammation networks.

In conclusion, the present study revealed that haplotypes of the TNFRSF4 gene were associated with EH among women in two Japanese populations, suggesting an involvement of the TNFRSF4 gene in the pathogenesis of female essential hypertension. 


\section{Acknowledgements}

We thank Naoto Ishii and Yoshihiro Onouchi for advice and assistance. We also thank Mieko Yoshida and Yoshiko Hotta for excellent technical assistance. 


\section{References}

1. Kearney PM, Whelton M, Reynolds K, Muntner P, Whelton PK, He J. Global burden of hypertension: analysis of worldwide data. Lancet 2005; 365:217-23.

2. Tanira MO, Al Balushi KA. Genetic variations related to hypertension: a review. J Hum Hypertens 2005; 19:7-19.

3. Cowley AW, Jr. The genetic dissection of essential hypertension. Nat Rev Genet 2006; 7:829-40.

4. Hubner N, Yagil C, Yagil Y. Novel integrative approaches to the identification of candidate genes in hypertension. Hypertension 2006; 47:1-5.

5. Nakayama T, Kuroi N, Sano M, Tabara Y, Katsuya T, Ogihara T, et al. Mutation of the follicle-stimulating hormone receptor gene 5'-untranslated region associated with female hypertension. Hypertension 2006; 48:512-8.

6. Calderhead DM, Buhlmann JE, van den Eertwegh AJ, Claassen E, Noelle RJ, Fell HP. Cloning of mouse Ox40: a $T$ cell activation marker that may mediate T-B cell interactions. J Immunol 1993; 151:5261-71.

7. Godfrey WR, Fagnoni FF, Harara MA, Buck D, Engleman EG. Identification of a human OX-40 ligand, a costimulator of CD4+ T cells with homology to tumor necrosis factor. J Exp Med 1994; 180:757-62.

8. Mallett S, Fossum S, Barclay AN. Characterization of the MRC OX40 antigen of activated CD4 positive T lymphocytes--a molecule related to nerve growth factor receptor. Embo J 1990; 9:1063-8.

9. Paterson DJ, Jefferies WA, Green JR, Brandon MR, Corthesy P, Puklavec M, et al. Antigens of activated rat $\mathrm{T}$ lymphocytes including a molecule of $50,000 \mathrm{Mr}$ detected only on CD4 positive T blasts. Mol Immunol 1987; 24:1281-90. 
10. Miura S, Ohtani K, Numata N, Niki M, Ohbo K, Ina Y, et al. Molecular cloning and characterization of a novel glycoprotein, gp34, that is specifically induced by the human T-cell leukemia virus type I transactivator p40tax. Mol Cell Biol 1991; 11:1313-25.

11. Akiba H, Miyahira Y, Atsuta M, Takeda K, Nohara C, Futagawa T, et al. Critical contribution of OX40 ligand to $T$ helper cell type 2 differentiation in experimental leishmaniasis. J Exp Med 2000; 191:375-80.

12. Imura A, Hori T, Imada K, Ishikawa T, Tanaka Y, Maeda M, et al. The human OX40/gp34 system directly mediates adhesion of activated $T$ cells to vascular endothelial cells. $J$ Exp Med 1996; 183:2185-95.

13. Stuber E, Neurath M, Calderhead D, Fell HP, Strober W. Cross-linking of OX40 ligand, a member of the TNF/NGF cytokine family, induces proliferation and differentiation in murine splenic B cells. Immunity 1995; 2:507-21.

14. Weinberg AD, Wegmann KW, Funatake C, Whitham RH. Blocking OX-40/OX-40 ligand interaction in vitro and in vivo leads to decreased $T$ cell function and amelioration of experimental allergic encephalomyelitis. J Immunol 1999; 162:1818-26.

15. Sugamura K, Ishii N, Weinberg AD. Therapeutic targeting of the effector T-cell co-stimulatory molecule OX40. Nat Rev Immunol 2004; 4:420-31.

16. Weinberg AD. OX40: targeted immunotherapy--implications for tempering autoimmunity and enhancing vaccines. Trends Immunol 2002; 23:102-9.

17. Weinberg AD, Evans DE, Thalhofer C, Shi T, Prell RA. The generation of T cell memory: a review describing the molecular and cellular events following OX40 (CD134) engagement. J Leukoc Biol 2004; 75:962-72.

18. Croft M. Co-stimulatory members of the TNFR family: keys to effective T-cell 
immunity? Nat Rev Immunol 2003; 3:609-20.

19. de Boer OJ, Becker AE, van der Wal AC. $T$ lymphocytes in atherogenesis-functional aspects and antigenic repertoire. Cardiovasc Res 2003; 60:78-86.

20. Hansson GK, Libby $P$, Schonbeck U, Yan ZQ. Innate and adaptive immunity in the pathogenesis of atherosclerosis. Circ Res 2002; 91:281-91.

21. Libby P, Ridker PM, Maseri A. Inflammation and atherosclerosis. Circulation 2002; 105:1135-43.

22. Wang X, Ria M, Kelmenson PM, Eriksson P, Higgins DC, Samnegard A, et al. Positional identification of TNFSF4, encoding OX40 ligand, as a gene that influences atherosclerosis susceptibility. Nat Genet 2005; 37:365-72.

23. Ria M, Eriksson P, Boquist S, Ericsson CG, Hamsten A, Lagercrantz J. Human genetic evidence that OX40 is implicated in myocardial infarction. Biochem Biophys Res Commun 2006; 339:1001-6.

24. Wilson PW. An epidemiologic perspective of systemic hypertension, ischemic heart disease, and heart failure. Am J Cardiol 1997; 80:3J-8J.

25. Samnegard A, Silveira A, Lundman P, Boquist S, Odeberg J, Hulthe J, et al. Serum matrix metalloproteinase-3 concentration is influenced by MMP-3 -1612 5A/6A promoter genotype and associated with myocardial infarction. $J$ Intern Med 2005; 258:411-9.

26. Sugimoto K, Katsuya T, Ohkubo T, Hozawa A, Yamamoto K, Matsuo A, et al. Association between angiotensin II type 1 receptor gene polymorphism and essential hypertension: the Ohasama Study. Hypertens Res 2004; 27:551-6.

27. 1999 World Health Organization-International Society of Hypertension Guidelines for the Management of Hypertension. Guidelines Subcommittee. $J$ 
Hypertens 1999; 17:151-83.

28. Kim HS, Krege JH, Kluckman KD, Hagaman JR, Hodgin JB, Best CF, et al. Genetic control of blood pressure and the angiotensinogen locus. Proc Natl Acad Sci U S A 1995; 92:2735-9.

29. Kim HS, Lee G, John SW, Maeda N, Smithies O. Molecular phenotyping for analyzing subtle genetic effects in mice: application to an angiotensinogen gene titration. Proc Natl Acad Sci U S A 2002; 99:4602-7.

30. Bannai M, Higuchi K, Akesaka T, Furukawa M, Yamaoka M, Sato K, et al. Single-nucleotide-polymorphism genotyping for whole-genome-amplified samples using automated fluorescence correlation spectroscopy. Anal Biochem 2004; 327:215-21.

31. Fujii K, Matsubara Y, Akanuma J, Takahashi K, Kure S, Suzuki Y, et al. Mutation detection by TaqMan-allele specific amplification: application to molecular diagnosis of glycogen storage disease type Ia and medium-chain acyl-CoA dehydrogenase deficiency. Hum Mutat 2000; 15:189-96.

32. Barbieri M, Ferrucci L, Corsi AM, Macchi C, Lauretani F, Bonafe M, et al. Is chronic inflammation a determinant of blood pressure in the elderly? Am $J$ Hypertens 2003; 16:537-43.

33. Derhaschnig U, Shehata M, Herkner H, Bur A, Woisetschlager C, Laggner AN, et al. Increased levels of transforming growth factor-beta1 in essential hypertension. Am J Hypertens 2002; 15:207-11.

34. Ferri C, Desideri G, Baldoncini R, Bellini C, De Angelis C, Mazzocchi C, et al. Early activation of vascular endothelium in nonobese, nondiabetic essential hypertensive patients with multiple metabolic abnormalities. Diabetes 1998; 47:660-7. 
35. Festa A, D'Agostino R, Jr., Howard G, Mykkanen L, Tracy RP, Haffner SM. Chronic subclinical inflammation as part of the insulin resistance syndrome: the Insulin Resistance Atherosclerosis Study (IRAS). Circulation 2000; 102:42-7.

36. Lakoski SG, Cushman M, Palmas W, Blumenthal R, D'Agostino RB, Jr., Herrington DM. The relationship between blood pressure and C-reactive protein in the Multi-Ethnic Study of Atherosclerosis (MESA). J Am Coll Cardiol 2005; 46:1869-74.

37. Parissis JT, Korovesis S, Giazitzoglou E, Kalivas P, Katritsis D. Plasma profiles of peripheral monocyte-related inflammatory markers in patients with arterial hypertension. Correlations with plasma endothelin-1. Int J Cardiol 2002; 83:13-21.

38. Pockley AG, De Faire U, Kiessling R, Lemne C, Thulin T, Frostegard J. Circulating heat shock protein and heat shock protein antibody levels in established hypertension. J Hypertens 2002; 20:1815-20.

39. Ridker PM, Buring JE, Cook NR,Rifai N. C-reactive protein, the metabolic syndrome, and risk of incident cardiovascular events: an 8-year follow-up of 14 719 initially healthy American women. Circulation 2003; 107:391-7.

40. Sung KC, Suh JY, Kim BS, Kang JH, Kim H, Lee MH, et al. High sensitivity C-reactive protein as an independent risk factor for essential hypertension. Am $\mathbf{J}$ Hypertens 2003; 16:429-33.

41. Yan JC, Ma GS, Wu ZG, Kong XT, Zong RQ, Zhan LZ. Increased levels of CD40-CD40 ligand system in patients with essential hypertension. Clin Chim Acta 2005; 355:191-6.

42. Dorffel Y, Latsch C, Stuhlmuller B, Schreiber S, Scholze S, Burmester GR, et al. Preactivated peripheral blood monocytes in patients with essential hypertension. 
Hypertension 1999; 34:113-7.

43. Grundy SM. Inflammation, hypertension, and the metabolic syndrome. Jama $2003 ; 290: 3000-2$

44. Li JJ. Inflammation in hypertension: primary evidence. Chin Med J (Engl) 2006; 119:1215-21.

45. Li JJ, Fang CH, Hui RT. Is hypertension an inflammatory disease? Med Hypotheses 2005; 64:236-40.

46. Sesso HD, Buring JE, Rifai N, Blake GJ, Gaziano JM, Ridker PM. C-reactive protein and the risk of developing hypertension. Jama 2003; 290:2945-51.

47. Bataillard A, Renaudin C, Sassard J. Silica attenuates hypertension in Lyon hypertensive rats. $J$ Hypertens 1995; 13:1581-4.

48. Bush E, Maeda N, Kuziel WA, Dawson TC, Wilcox JN, DeLeon H, et al. CC chemokine receptor 2 is required for macrophage infiltration and vascular hypertrophy in angiotensin II-induced hypertension. Hypertension 2000; $36: 360-3$.

49. Clozel M, Kuhn H, Hefti F, Baumgartner HR. Endothelial dysfunction and subendothelial monocyte macrophages in hypertension. Effect of angiotensin converting enzyme inhibition. Hypertension 1991; 18:132-41.

50. Haller H, Behrend M, Park JK, Schaberg T, Luft FC, Distler A. Monocyte infiltration and c-fms expression in hearts of spontaneously hypertensive rats. Hypertension 1995; 25:132-8.

51. Hilgers KF, Hartner A, Porst M, Mai M, Wittmann M, Hugo C, et al. Monocyte chemoattractant protein-1 and macrophage infiltration in hypertensive kidney injury. Kidney Int 2000; 58:2408-19.

52. Johnson RJ, Alpers CE, Yoshimura A, Lombardi D, Pritzl P, Floege J, et al. 
Renal injury from angiotensin II-mediated hypertension. Hypertension 1992; 19:464-74.

53. McCarron RM, Wang L, Siren AL, Spatz M, Hallenbeck JM. Monocyte adhesion to cerebromicrovascular endothelial cells derived from hypertensive and normotensive rats. Am J Physiol 1994; 267:H2491-7.

54. Schmid-Schonbein GW, Seiffge D, DeLano FA, Shen K, Zweifach BW. Leukocyte counts and activation in spontaneously hypertensive and normotensive rats. Hypertension 1991; 17:323-30.

55. Herrington DM, Brown WV, Mosca L, Davis W, Eggleston B, Hundley WG, et al. Relationship between arterial stiffness and subclinical aortic atherosclerosis. Circulation 2004; 110:432-7.

56. van Popele NM, Grobbee DE, Bots ML, Asmar R, Topouchian J, Reneman RS, et al. Association between arterial stiffness and atherosclerosis: the Rotterdam Study. Stroke 2001; 32:454-60.

57. Dernellis J, Panaretou M. Aortic stiffness is an independent predictor of progression to hypertension in nonhypertensive subjects. Hypertension 2005; 45:426-31.

58. Liao D, Arnett DK, Tyroler HA, Riley WA, Chambless LE, Szklo M, et al. Arterial stiffness and the development of hypertension. The ARIC study. Hypertension 1999; 34:201-6.

59. Franklin SS. Arterial stiffness and hypertension: a two-way street? Hypertension 2005; 45:349-51.

60. O'Donnell CJ, Lindpaintner K, Larson MG, Rao VS, Ordovas JM, Schaefer EJ, et al. Evidence for association and genetic linkage of the angiotensin-converting enzyme locus with hypertension and blood pressure in men but not women in the 
Framingham Heart Study. Circulation 1998; 97:1766-72.

61. Ono K, Mannami T, Iwai N. Association of a promoter variant of the haeme oxygenase-1 gene with hypertension in women. $J$ Hypertens 2003; 21:1497-503.

62. Aittomaki K, Lucena JL, Pakarinen P, Sistonen P, Tapanainen J, Gromoll J, et al. Mutation in the follicle-stimulating hormone receptor gene causes hereditary hypergonadotropic ovarian failure. Cell 1995; 82:959-68.

63. Stork S, van der Schouw YT, Grobbee DE, Bots ML. Estrogen, inflammation and cardiovascular risk in women: a critical appraisal. Trends Endocrinol Metab 2004; 15:66-72.

64. Rosano GM, Vitale C, Marazzi G, Volterrani M. Menopause and cardiovascular disease: the evidence. Climacteric 2007; 10 Suppl 1:19-24.

65. Nilsson BO. Modulation of the inflammatory response by estrogens with focus on the endothelium and its interactions with leukocytes. Inflamm Res 2007; 56:269-73.

66. Xing D, Feng W, Miller AP, Weathington NM, Chen YF, Novak L, et al. Estrogen modulates TNF-alpha-induced inflammatory responses in rat aortic smooth muscle cells through estrogen receptor-beta activation. Am J Physiol Heart Circ Physiol 2007; 292:H2607-12. 
Tables

(Table 1) Characteristics of subjects in population 1

\begin{tabular}{|c|c|c|c|c|c|c|c|c|c|}
\hline \multirow[b]{2}{*}{ Parameters } & \multicolumn{3}{|c|}{ Total subjects } & \multicolumn{3}{|c|}{ Male subjects } & \multicolumn{3}{|c|}{ Female subjects } \\
\hline & NT & HT & $P$ & NT & HT & $P$ & NT & HT & $P$ \\
\hline No. of subjects & 562 & 587 & & 301 & 316 & & 261 & 271 & \\
\hline Age (years) & $61.6 \pm 9.2$ & $60.1 \pm 11.2$ & $0.011^{*}$ & $59.9 \pm 9.0$ & $58.5 \pm 11.1$ & 0.083 & $63.6 \pm 9.1$ & $62.0 \pm 11.1$ & 0.056 \\
\hline BMI $\left(\mathrm{kg} / \mathrm{m}^{2}\right)$ & $22.2 \pm 2.8$ & $23.9 \pm 3.3$ & $<0.001^{*}$ & $22.1 \pm 2.9$ & $23.8 \pm 3.1$ & $<0.001 *$ & $22.3 \pm 2.7$ & $24.0 \pm 3.6$ & $<0.001^{*}$ \\
\hline $\mathrm{SBP}(\mathrm{mmHg})$ & $111.7 \pm 8.9$ & $163.7 \pm 21.1$ & $<0.001^{*}$ & $111.8 \pm 8.8$ & $162.1 \pm 18.4$ & $<0.001 *$ & $111.5 \pm 9.1$ & $166.1 \pm 24.4$ & $<0.001^{*}$ \\
\hline DBP (mmHg) & $68.9 \pm 7.3$ & $98.3 \pm 14.8$ & $<0.001^{*}$ & $69.4 \pm 7.3$ & $98.7 \pm 14.0$ & $<0.001 *$ & $68.0 \pm 7.3$ & $97.6 \pm 16.0$ & $<0.001^{*}$ \\
\hline $\mathrm{TC}(\mathrm{mg} / \mathrm{dl})$ & $205.5 \pm 38.0$ & $207.1 \pm 34.9$ & 0.596 & $195.8 \pm 35.7$ & $198.7 \pm 33.0$ & 0.294 & $216.2 \pm 37.6$ & $216.0 \pm 34.7$ & 0.970 \\
\hline HDL-C (mg/dl) & $57.3 \pm 15.1$ & $58.3 \pm 17.2$ & 0.314 & $55.3 \pm 15.0$ & $56.8 \pm 17.5$ & 0.263 & $59.5 \pm 15.0$ & $60.0 \pm 16.7$ & 0.697 \\
\hline $\mathrm{TG}(\mathrm{mg} / \mathrm{dl})$ & $123.8 \pm 87.4$ & $141.7 \pm 84.7$ & $0.003 *$ & $132.1 \pm 106.2$ & $147.0 \pm 94.5$ & 0.133 & $116.7 \pm 67.4$ & $135.4 \pm 71.3$ & $0.007^{*}$ \\
\hline
\end{tabular}

Values are mean \pm SD. NT, normotensive; HT, hypertensive; BMI, body mass index; SBP, systolic blood pressure; DBP, diastolic blood pressure;

TC, total cholesterol; HDL-C, HDL cholesterol; TG, triglyceride.

* Significant difference. 
(Table 2) Characteristics of subjects in population 2

\begin{tabular}{|c|c|c|c|c|c|c|c|c|c|}
\hline \multirow[b]{2}{*}{ Parameters } & \multicolumn{3}{|c|}{ Total subjects } & \multicolumn{3}{|c|}{ Male subjects } & \multicolumn{3}{|c|}{ Female subjects } \\
\hline & NT & HT & $P$ & NT & HT & $P$ & NT & HT & $P$ \\
\hline No. of subjects & 925 & 732 & & 317 & 323 & & 608 & 409 & \\
\hline Age (years) & $54.6 \pm 11.5$ & $61.6 \pm 9.7$ & $<0.001 *$ & $55.8 \pm 11.1$ & $61.5 \pm 10.2$ & $<0.001 *$ & $54.0 \pm 11.6$ & $61.7 \pm 9.3$ & $<0.001 *$ \\
\hline BMI $\left(\mathrm{kg} / \mathrm{m}^{2}\right)$ & $23.4 \pm 3.1$ & $24.2 \pm 3.3$ & $<0.001 *$ & $23.5 \pm 3.0$ & $23.6 \pm 3.1$ & 0.506 & $23.4 \pm 3.1$ & $24.6 \pm 3.4$ & $<0.001 *$ \\
\hline $\mathrm{SBP}(\mathrm{mmHg})$ & $123.9 \pm 9.8$ & $142.2 \pm 12.1$ & $<0.001 *$ & $125.4 \pm 8.6$ & $143.9 \pm 11.4$ & $<0.001 *$ & $123.1 \pm 10.3$ & $140.8 \pm 12.5$ & $<0.001 *$ \\
\hline DBP (mmHg) & $70.3 \pm 7.1$ & $80.2 \pm 9.1$ & $<0.001 *$ & $71.6 \pm 6.9$ & $81.9 \pm 9.4$ & $<0.001 *$ & $69.6 \pm 7.2$ & $78.8 \pm 8.6$ & $<0.001 *$ \\
\hline $\mathrm{TC}(\mathrm{mg} / \mathrm{dl})$ & $193.4 \pm 34.2$ & $195.0 \pm 33.8$ & 0.358 & $186.4 \pm 33.8$ & $183.9 \pm 34.0$ & 0.352 & $197.1 \pm 33.9$ & $203.8 \pm 31.0$ & $0.001 *$ \\
\hline HDL-C (mg/dl) & $55.3 \pm 14.1$ & $53.8 \pm 14.6$ & $0.028^{*}$ & $51.2 \pm 14.1$ & $52.8 \pm 14.4$ & 0.180 & $57.4 \pm 13.7$ & $54.4 \pm 14.7$ & $0.001 *$ \\
\hline $\mathrm{TG}(\mathrm{mg} / \mathrm{dl})$ & $128.9 \pm 73.4$ & $142.5 \pm 89.8$ & $0.001 *$ & $139.1 \pm 85.1$ & $146.3 \pm 103.0$ & 0.340 & $123.7 \pm 66.1$ & $139.5 \pm 77.9$ & $0.001 *$ \\
\hline
\end{tabular}

Values are mean \pm SD. NT, normotensive; HT, hypertensive; BMI, body mass index; SBP, systolic blood pressure; DBP, diastolic blood pressure;

TC, total cholesterol; HDL-C, HDL cholesterol; TG, triglyceride.

* Significant difference. 
(Table 3) Primer sequence (5' $\rightarrow 3^{\prime}$ ') for TaqMan-ASA genotyping

\begin{tabular}{lllc}
\hline SNP & Allele specific primer & Common primer & TaqMan probe $^{\text {a }}$ \\
\hline \hline P1 & CACATGGCTGGAATTTACCATC & CTCAGCAGTGGGAGAAAAACAA & CCTCTGAAGCGTTTTCACTGGTATCATGTGT \\
& CACATGGCTGGAATTTACCTCT & & \\
\hline P2 & GTCGCCTTTCCCCCTCCG & GCTGCAGCCAATAGGCACCTT & AATAGCCACTTCGTGCGGCTGG \\
& GTCGCCTTTCCCCCTCCA & & TGAGCTCTGGGTCAGTGTCCA \\
\hline P8 & $\begin{array}{l}\text { GTCACAGGTCCAAGAAAGCCGT } \\
\text { GTCACAGGTCCAAGAAAGCCGC }\end{array}$ & GCAGGCTGCCTTACAGACCTT & \\
\hline P12 & $\begin{array}{l}\text { GGTCAGGAGTTCAAGACCAGTGT } \\
\text { GGTCAGGAGTTCAAGACCAGTTC }\end{array}$ & CCACGCCCGAATAATTTTTG & AGTAGAGACGGGATTTCGCCATGTTAGC \\
${ }^{\text {a }}$ TaqMan probes contained a 5'FAM (6-carboxyfluorescein) reporter fluorophore and a 3' TAMRA (6-carboxytetramethylrhodamine) quencher.
\end{tabular}


(Table 4) Polymorphisms with minor allele frequencies $\geq 5 \%$ detected in the TNFRSF4 genomic region in 32 Japanese controls

\begin{tabular}{|c|c|c|c|c|c|c|}
\hline Name & Polymorphism ${ }^{a}$ & Location & $\begin{array}{l}\text { Amino acid } \\
\text { change }\end{array}$ & MAF $^{\mathrm{b}}$ & dbSNP ID & JSNP ID \\
\hline $\mathrm{P} 1$ & $-3943 C>T$ & 5' Flanking & & 0.06 & & \\
\hline $\mathrm{P} 2$ & $-3601 \mathrm{C}>\mathrm{T}$ & 5' Flanking & & 0.27 & rs 12036216 & \\
\hline P3 & $-3119 \mathrm{G}>\mathrm{T}$ & 5' Flanking & & 0.27 & rs11721 & \\
\hline P4 & $-2577 \mathrm{delA}$ & 5' Flanking & & 0.22 & & \\
\hline P5 & $-2568 C>G$ & 5' Flanking & & 0.06 & & \\
\hline P6 & $-2461 C>G$ & 5' Flanking & & 0.27 & & \\
\hline P7 & $-2167 \mathrm{C}>\mathrm{T}$ & 5' Flanking & & 0.06 & & \\
\hline P8 & $-1720 A>G$ & 5' Flanking & & 0.30 & rs3813201 & JST-IMS 173304 \\
\hline P9 & $-936 A>G$ & 5' Flanking & & 0.19 & rs34115518 & \\
\hline $\mathrm{P} 10$ & $-699 \mathrm{C}>\mathrm{T}$ & 5' Flanking & & 0.16 & rs35339498 & \\
\hline P11 & $-669 C>G$ & 5' Flanking & & 0.19 & rs35659545 & \\
\hline P12 & $-525 \mathrm{~A}>\mathrm{G}$ & 5' Flanking & & 0.11 & rs35107976 & \\
\hline P13 & $150+47 \mathrm{G}>\mathrm{C}$ & Intron1 & & 0.11 & rs35737009 & \\
\hline P14 & $376-16 \mathrm{C}>\mathrm{G}$ & Intron3 & & 0.11 & rs34108055 & \\
\hline P15 & $442+32$ ins $35 b p$ & Intron4 & & 0.25 & & \\
\hline P16 & $442+248 \mathrm{C}>\mathrm{T}$ & Intron4 & & 0.19 & rs9661697 & \\
\hline P17 & $539 \mathrm{G}>\mathrm{A}$ & Exon5 & Glu178Glu & 0.25 & rs17568 & \\
\hline P18 & $639+25 \mathrm{C}>\mathrm{T}$ & Intron5 & & 0.19 & rs2298212 & JST-IMS053053 \\
\hline P19 & $640-31 \mathrm{~T}>\mathrm{G}$ & Intron5 & & 0.20 & rs2298211 & JST-IMS053052 \\
\hline P20 & $921 \mathrm{C}>\mathrm{T}$ & Exon7 (3' UTR) & & 0.11 & rs2298210 & JST-IMS053051 \\
\hline $\mathrm{P} 21$ & $989 \mathrm{C}>\mathrm{G}$ & Exon7 (3' UTR) & & 0.11 & rs2298209 & JST-IMS053050 \\
\hline $\mathrm{P} 22$ & $1067+308 \mathrm{G}>\mathrm{A}$ & 3' Flanking & & 0.08 & rs2298208 & JST-IMS053049 \\
\hline $\mathrm{P} 23$ & $1067+941 G>C$ & 3' Flanking & & 0.20 & rs34067070 & \\
\hline P24 & $1067+1224 d e l T T$ & 3' Flanking & & 0.20 & & \\
\hline P25 & $1067+1240 \mathrm{G}>\mathrm{C}$ & 3' Flanking & & 0.20 & rs34279802 & \\
\hline P26 & $1067+1266 \mathrm{~T}>\mathrm{C}$ & 3' Flanking & & 0.20 & rs35916760 & \\
\hline $\mathrm{P} 27$ & $1067+1296 C>T$ & 3' Flanking & & 0.20 & rs36057244 & \\
\hline
\end{tabular}

${ }^{a}$ Numbering according to the cDNA sequence of TNFRSF4 (accession number NM_003327).

${ }^{\mathrm{b}}$ Minor allele frequency (MAF) on the basis of the sequencing of 32 DNA samples. 
(Table 5) Genotype and allele frequencies among NT and HT subjects in population 1

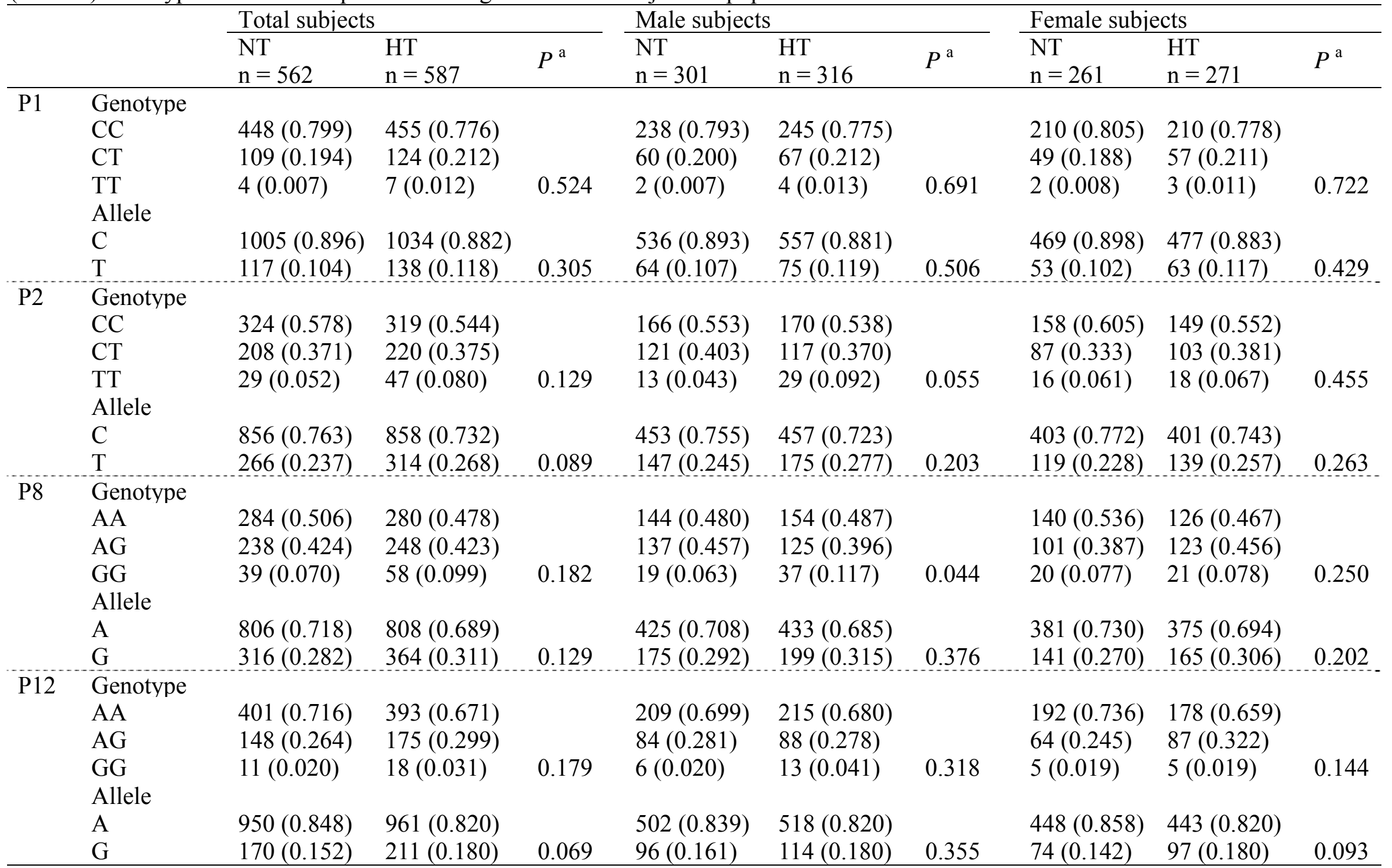

${ }^{a}$ Significant $P$-value after Bonferroni's correction for four loci is $0.0125(0.05 / 4)$. 
(Table 6) 4-SNP haplotype (P1-P2-P8-P12) frequency among NT and HT subjects in population 1

\begin{tabular}{|c|c|c|c|c|c|c|c|c|c|}
\hline & \multirow[b]{2}{*}{ Haplotype ${ }^{\text {a }}$} & \multicolumn{4}{|c|}{ Male subjects } & \multicolumn{4}{|c|}{ Female subjects } \\
\hline & & $\begin{array}{l}\text { NT } \\
\mathrm{n}=298\end{array}$ & $\begin{array}{l}\text { HT } \\
n=316\end{array}$ & $P^{\mathrm{b}}$ & $\begin{array}{l}\text { Permutation } \\
P\end{array}$ & $\begin{array}{l}\text { NT } \\
n=261\end{array}$ & $\begin{array}{l}\text { HT } \\
n=270\end{array}$ & $P^{\mathrm{b}}$ & $\begin{array}{l}\text { Permutation } \\
P\end{array}$ \\
\hline $\mathrm{H} 1$ & C-C-A-A & $404(0.677)$ & $413(0.653)$ & 0.371 & 0.363 & $376(0.720)$ & $356(0.659)$ & 0.031 & $0.021 *$ \\
\hline $\mathrm{H} 2$ & C-T-G-A & $81(0.136)$ & $96(0.152)$ & 0.419 & 0.420 & $60(0.116)$ & $75(0.138)$ & 0.267 & 0.259 \\
\hline $\mathrm{H} 3$ & T-T-G-G & $63(0.106)$ & $73(0.115)$ & 0.584 & 0.559 & $52(0.099)$ & $62(0.115)$ & 0.405 & 0.402 \\
\hline H4 & C-C-G-G & $16(0.026)$ & $21(0.033)$ & 0.484 & 0.470 & $17(0.033)$ & $14(0.027)$ & 0.578 & 0.617 \\
\hline H5 & C-C-A-G & $17(0.029)$ & $18(0.029)$ & 0.967 & 0.958 & $1(0.002)$ & $19(0.036)$ & $6.78 \times 10^{-5} *$ & $<0.001 *$ \\
\hline \multirow[t]{2}{*}{ H6 } & C-C-G-A & $12(0.021)$ & $5(0.008)$ & 0.063 & 0.066 & $9(0.018)$ & $12(0.021)$ & 0.646 & 0.682 \\
\hline & others & $3(0.005)$ & $6(0.010)$ & & & $7(0.013)$ & $2(0.004)$ & & \\
\hline \multicolumn{2}{|c|}{ Entire distribution } & & & & $0.722^{\mathrm{c}}$ & & & & $0.003^{\mathrm{c},} *$ \\
\hline
\end{tabular}

${ }^{a}$ Four loci are P1, P2, P8, P12, and six predominant haplotypes are listed; "others" category includes minor haplotypes with $<1 \%$ frequency.

${ }^{\mathrm{b}}$ Significant $P$-value after Bonferroni correction for major six haplotypes is $0.0083(0.05 / 6)$.

${ }^{\mathrm{c}} P$-value for the entire distribution with permutation test.

* Significant difference. 
(Table 7) Genotype and allele frequencies among NT and HT subjects in population 2

\begin{tabular}{|c|c|c|c|c|c|c|c|c|c|c|}
\hline & & \multicolumn{3}{|l|}{ Total subjects } & \multicolumn{3}{|c|}{ Male subjects } & \multicolumn{3}{|c|}{ Female subjects } \\
\hline & & $\begin{array}{l}\text { NT } \\
\mathrm{n}=925\end{array}$ & $\begin{array}{l}\text { HT } \\
n=732\end{array}$ & $P^{\mathrm{a}}$ & $\begin{array}{l}\text { NT } \\
\mathrm{n}=317\end{array}$ & $\begin{array}{l}\text { HT } \\
n=323\end{array}$ & $P^{\mathrm{a}}$ & $\begin{array}{l}\text { NT } \\
\mathrm{n}=608\end{array}$ & $\begin{array}{l}\text { HT } \\
n=409\end{array}$ & $P^{\mathrm{a}}$ \\
\hline \multirow[t]{7}{*}{ P1 } & Genotype & & & & & & & & & \\
\hline & $\mathrm{CC}$ & $729(0.792)$ & $573(0.786)$ & & $253(0.801)$ & $249(0.778)$ & & $476(0.788)$ & $324(0.792)$ & \\
\hline & CT & $181(0.197)$ & $147(0.202)$ & & $58(0.184)$ & $66(0.206)$ & & $123(0.204)$ & $81(0.198)$ & \\
\hline & TT & $10(0.011)$ & $9(0.012)$ & 0.929 & $5(0.016)$ & $5(0.016)$ & 0.770 & $5(0.008)$ & $4(0.010)$ & 0.949 \\
\hline & Allele & & & & & & & & & \\
\hline & $\mathrm{C}$ & $1639(0.891)$ & $1293(0.887)$ & & $564(0.892)$ & $564(0.881)$ & & $1075(0.890)$ & $729(0.891)$ & \\
\hline & $\mathrm{T}$ & $201(0.109)$ & $165(0.113)$ & 0.721 & $68(0.108)$ & $76(0.119)$ & 0.530 & $133(0.110)$ & $89(0.109)$ & 0.927 \\
\hline \multirow[t]{7}{*}{$\mathrm{P} 2$} & Genotype & & & & & & & & & \\
\hline & $\mathrm{CC}$ & $550(0.598)$ & $403(0.553)$ & & $176(0.555)$ & $182(0.567)$ & & $374(0.620)$ & $221(0.542)$ & \\
\hline & $\mathrm{CT}$ & $323(0.351)$ & $282(0.387)$ & & $118(0.372)$ & $123(0.383)$ & & $205(0.340)$ & $159(0.390)$ & \\
\hline & TT & $47(0.051)$ & $44(0.060)$ & 0.176 & $23(0.073)$ & $16(0.050)$ & 0.488 & $24(0.040)$ & $28(0.069)$ & 0.017 \\
\hline & Allele & & & & & & & & & \\
\hline & $\mathrm{C}$ & $1423(0.773)$ & $1088(0.746)$ & & $470(0.741)$ & $487(0.759)$ & & $953(0.790)$ & $601(0.737)$ & \\
\hline & $\mathrm{T}$ & $417(0.227)$ & $370(0.254)$ & 0.069 & $164(0.259)$ & $155(0.241)$ & 0.477 & $253(0.210)$ & $215(0.263)$ & $0.005 *$ \\
\hline \multirow[t]{7}{*}{ P8 } & Genotype & & & & & & & & & \\
\hline & $\mathrm{AA}$ & $464(0.508)$ & $342(0.472)$ & & $146(0.465)$ & $157(0.489)$ & & $318(0.530)$ & $185(0.458)$ & \\
\hline & AG & $384(0.420)$ & $316(0.436)$ & & $139(0.443)$ & $143(0.445)$ & & $245(0.408)$ & $173(0.428)$ & \\
\hline & GG & $66(0.072)$ & $67(0.092)$ & 0.189 & $29(0.092)$ & $21(0.065)$ & 0.436 & $37(0.062)$ & $46(0.114)$ & $0.005 *$ \\
\hline & Allele & & & & & & & & & \\
\hline & A & $1312(0.718)$ & $1000(0.690)$ & & $431(0.686)$ & $457(0.712)$ & & $881(0.734)$ & $543(0.672)$ & \\
\hline & $\mathrm{G}$ & $516(0.282)$ & $450(0.310)$ & 0.080 & $197(0.314)$ & $185(0.288)$ & 0.321 & $319(0.266)$ & $265(0.328)$ & $0.003 *$ \\
\hline \multirow[t]{7}{*}{$\mathrm{P} 12$} & Genotype & & & & & & & & & \\
\hline & AA & $630(0.686)$ & $479(0.659)$ & & $214(0.677)$ & $208(0.650)$ & & $416(0.691)$ & $271(0.666)$ & \\
\hline & $\mathrm{AG}$ & $265(0.289)$ & $220(0.303)$ & & $93(0.294)$ & $100(0.313)$ & & $172(0.286)$ & $120(0.295)$ & \\
\hline & GG & $23(0.025)$ & $28(0.039)$ & 0.213 & $9(0.028)$ & $12(0.038)$ & 0.690 & $14(0.023)$ & $16(0.039)$ & 0.301 \\
\hline & Allele & & & & & & & & & \\
\hline & $\mathrm{A}$ & $1525(0.831)$ & $1178(0.810)$ & & $521(0.824)$ & $516(0.806)$ & & $1004(0.834)$ & $662(0.813)$ & \\
\hline & G & $311(0.169)$ & $276(0.190)$ & 0.128 & $111(0.176)$ & $124(0.194)$ & 0.405 & $200(0.166)$ & $152(0.187)$ & 0.231 \\
\hline
\end{tabular}

${ }^{a}$ Significant $P$-value after Bonferroni's correction for four loci is $0.0125(0.05 / 4)$.

* Significant difference. 
(Table 8) 4-SNP haplotype (P1-P2-P8-P12) frequency among NT and HT subjects in population 2

\begin{tabular}{|c|c|c|c|c|c|c|c|c|c|}
\hline & \multirow[b]{2}{*}{$\underset{\mathrm{a}}{\text { Haplotype }}$} & \multicolumn{4}{|c|}{ Male subjects } & \multicolumn{4}{|c|}{ Female subjects } \\
\hline & & $\begin{array}{l}\text { NT } \\
n=303\end{array}$ & $\begin{array}{l}\text { HT } \\
n=299\end{array}$ & $P^{\mathrm{b}}$ & $\begin{array}{l}\text { Permutation } \\
P\end{array}$ & $\begin{array}{l}\text { NT } \\
\mathrm{n}=584\end{array}$ & $\begin{array}{l}\text { HT } \\
n=388\end{array}$ & $P^{\mathrm{b}}$ & $\begin{array}{l}\text { Permutation } \\
P\end{array}$ \\
\hline H1 & C-C-A-A & $403(0.665)$ & $403(0.674)$ & 0.743 & 0.714 & $839(0.718)$ & $502(0.647)$ & $8.48 \times 10^{-4} *$ & $<0.001 *$ \\
\hline $\mathrm{H} 2$ & C-T-G-A & $86(0.142)$ & $75(0.125)$ & 0.400 & 0.388 & $115(0.098)$ & $116(0.149)$ & $6.46 \times 10^{-4} *$ & $0.001 *$ \\
\hline H3 & T-T-G-G & $66(0.109)$ & $71(0.119)$ & 0.592 & 0.593 & $125(0.107)$ & $84(0.108)$ & 0.939 & 0.926 \\
\hline H4 & C-C-G-G & $30(0.049)$ & $24(0.040)$ & 0.429 & 0.443 & $47(0.040)$ & $45(0.058)$ & 0.067 & 0.074 \\
\hline H5 & C-C-A-G & $11(0.018)$ & $20(0.034)$ & 0.095 & 0.113 & $21(0.018)$ & $18(0.023)$ & 0.434 & 0.451 \\
\hline H6 & C-C-G-A & $8(0.014)$ & $4(0.007)$ & 0.265 & 0.374 & $15(0.013)$ & $8(0.010)$ & 0.606 & 0.583 \\
\hline & others & $2(0.003)$ & $1(0.002)$ & & & $6(0.005)$ & $3(0.004)$ & & \\
\hline
\end{tabular}

Entire

distribution

$0.533^{\mathrm{c}}$

$0.026^{\mathrm{c}, *}$

${ }^{a}$ Four loci are P1, P2, P8, P12, and six predominant haplotypes are listed; "others" category includes minor haplotypes with $<1 \%$ frequency.

${ }^{\mathrm{b}}$ Significant $P$-value after Bonferroni correction for major six haplotypes is $0.0083(0.05 / 6)$.

${ }^{c} P$-value for the entire distribution with permutation test.

* Significant difference. 
(Table 9) 4-SNP haplotype (P1-P2-P8-P12) frequency among NT and HT subjects in the combined population (populations 1 and 2)

\begin{tabular}{|c|c|c|c|c|c|c|c|}
\hline & \multirow[b]{2}{*}{ Haplotype $^{\mathrm{a}}$} & \multicolumn{3}{|c|}{ Male subjects } & \multicolumn{3}{|c|}{ Female subjects } \\
\hline & & $\begin{array}{l}\mathrm{NT} \\
\mathrm{n}=602\end{array}$ & $\begin{array}{l}\text { HT } \\
n=615\end{array}$ & $P^{\mathrm{b}}$ & $\begin{array}{l}\text { NT } \\
\mathrm{n}=845\end{array}$ & $\begin{array}{l}\text { HT } \\
n=658\end{array}$ & $P^{\mathrm{b}}$ \\
\hline $\mathrm{H} 1$ & C-C-A-A & $806(0.671)$ & $816(0.663)$ & 0.682 & $1215(0.719)$ & $858(0.652)$ & $8.07 \times 10^{-5} *$ \\
\hline $\mathrm{H} 2$ & C-T-G-A & $167(0.139)$ & $171(0.139)$ & 0.989 & $175(0.104)$ & $191(0.145)$ & $6.07 \times 10^{-4} *$ \\
\hline $\mathrm{H} 3$ & T-T-G-G & $129(0.107)$ & $144(0.117)$ & 0.446 & $177(0.104)$ & $146(0.111)$ & 0.578 \\
\hline $\mathrm{H} 4$ & C-C-G-G & $45(0.038)$ & $45(0.036)$ & 0.846 & $64(0.038)$ & $60(0.045)$ & 0.306 \\
\hline H5 & C-C-A-G & $29(0.024)$ & $38(0.031)$ & 0.263 & $22(0.013)$ & $37(0.028)$ & $0.003 *$ \\
\hline H6 & C-C-G-A & $21(0.017)$ & $9(0.008)$ & 0.033 & $24(0.014)$ & $20(0.015)$ & 0.906 \\
\hline & others & $5(0.004)$ & $7(0.006)$ & & $13(0.008)$ & $6(0.004)$ & \\
\hline
\end{tabular}

\footnotetext{
${ }^{a}$ Four loci are P1, P2, P8, P12, and six predominant haplotypes are listed; "others" category includes minor haplotypes with $<1 \%$ frequency.

${ }^{\mathrm{b}}$ Significant $P$-value after Bonferroni correction for major six haplotypes is $0.0083(0.05 / 6)$.

* Significant difference.
} 


\section{Figures}

(Fig. 1)

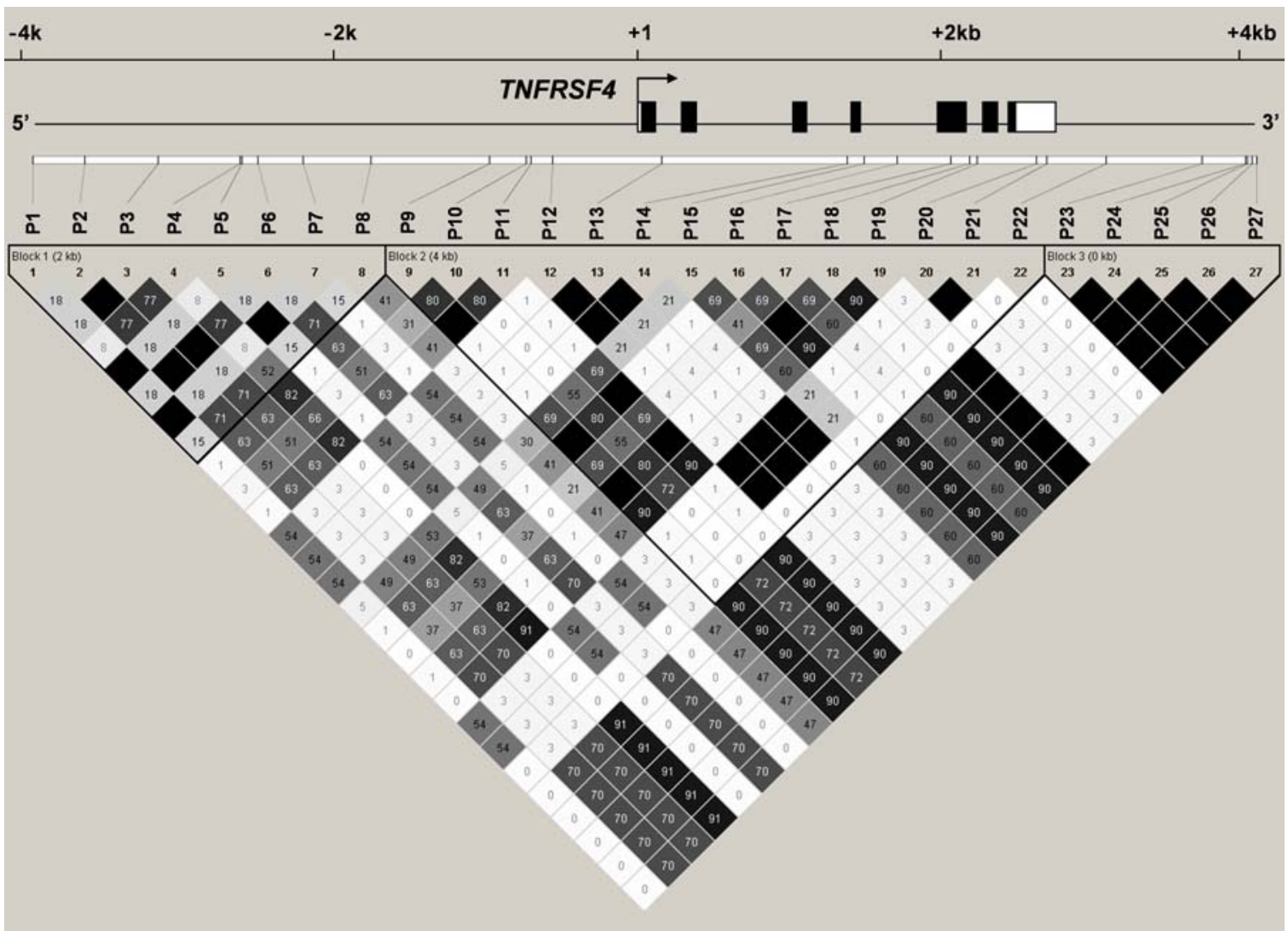


(Fig. 2)

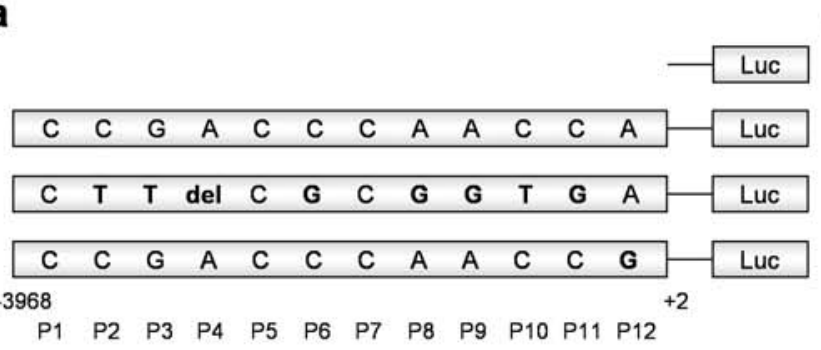

b

\begin{tabular}{|lllllllllllll}
\hline C & $C$ & $G$ & $A$ & $C$ & $C$ & $C$ & $A$ & $A$ & $C$ & $C$ & $A$ & Luc \\
\hline
\end{tabular}

\begin{tabular}{llllllllllllllllllllllll}
\hline$C$ & $T$ & $G$ & $A$ & $C$ & $C$ & $C$ & $A$ & $A$ & $C$ & $C$ & $A$ & Luc \\
\hline
\end{tabular}

\begin{tabular}{|llllllllllllll}
\hline C & C & T & A & C & C & C & A & A & C & C & A & Luc \\
\hline
\end{tabular}

\begin{tabular}{lllllllllllll}
\hline & $C$ & $G$ & del & $C$ & $C$ & $C$ & $A$ & $A$ & $C$ & $C$ & $A$ \\
\hline
\end{tabular}

\begin{tabular}{lllllllllllll}
\hline C & $C$ & $G$ & $A$ & $C$ & $G$ & $C$ & $A$ & $A$ & $C$ & $C$ & $A$ \\
\hline
\end{tabular}

\begin{tabular}{lllllllllllll}
\hline C & C & $G$ & A & C & C & C & G & A & C & C & A & Luc \\
\hline
\end{tabular}

\begin{tabular}{|lllllllllllll}
\hline$C$ & $C$ & $G$ & $A$ & $C$ & $C$ & $C$ & $A$ & $G$ & $C$ & $C$ & $A$ \\
\hline
\end{tabular}

\begin{tabular}{lllllllllllllllllll}
\hline$C$ & $C$ & $G$ & $A$ & $C$ & $C$ & $C$ & $A$ & $A$ & $T$ & $C$ & $A$ & Luc & Pr-P10-T
\end{tabular}

\begin{tabular}{|lllllllllllll}
\hline C & C & G & A & C & C & C & A & A & C & G & A & Luc \\
\hline
\end{tabular} $-3968$

$\begin{array}{lllllllllllll}\text { P1 } & \text { P2 } & \text { P3 } & \text { P4 } & \text { P5 } & \text { P6 } & \text { P7 } & \text { P8 } & \text { P9 } & \text { P10 } & \text { P11 } & \text { P12 } & \end{array}$ (cos-7)

PGL4.10

$\mathrm{Pr}-\mathrm{H} 1$

$\mathrm{Pr}-\mathrm{H} 2$

$\mathrm{Pr}-\mathrm{H} 5$

$\begin{array}{llllllll}0.0 & 0.2 & 0.4 & 0.6 & 0.8 & 1.0 & 1.2 & 1.4\end{array}$

Relative luciferase activity

(COS-7)
Pr-H1
Pr-P2-T
Pr-P3-T
Pr-P4-del
Pr-P6-G
Pr-P8-G
Pr-P9-G
Pr-P10-T
Pr-P11-G

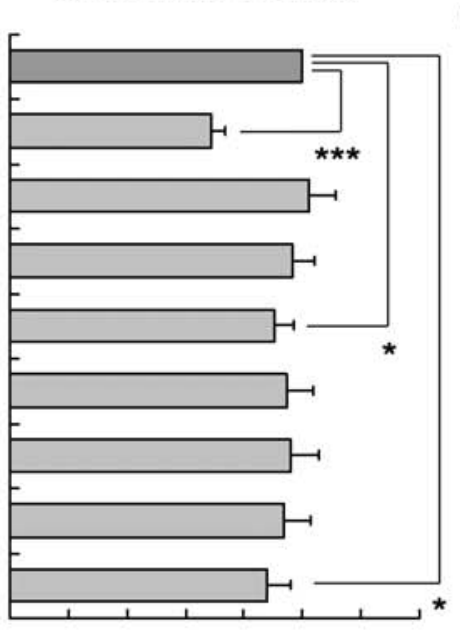

$\begin{array}{llllllll}0.0 & 0.2 & 0.4 & 0.6 & 0.8 & 1.0 & 1.2 & 1.4\end{array}$

Relative luciferase activity

C (HEK293)

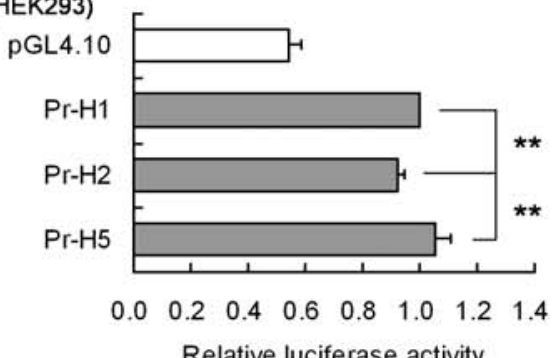

d (HEK293)

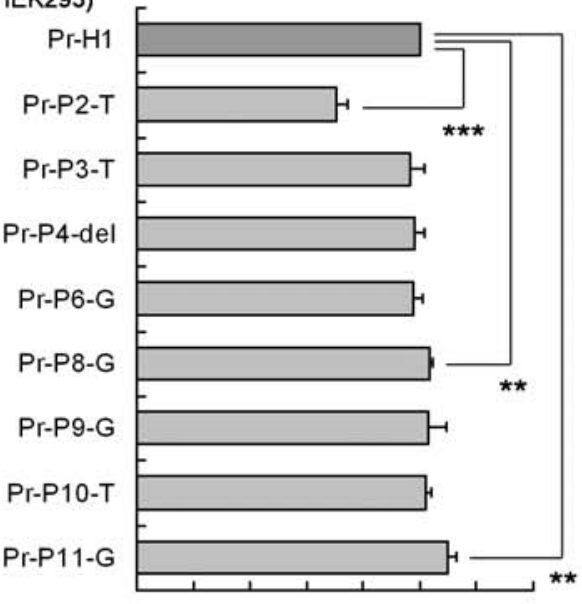

$\begin{array}{llllllll}0.0 & 0.2 & 0.4 & 0.6 & 0.8 & 1.0 & 1.2 & 1.4\end{array}$

Relative luciferase activity 


\section{Figure Legends}

(Fig. 1)

Haplotype block structure of the TNFRSF4 gene. Top Organization of the TNFRSF4 gene. Exons are indicated by boxes (black, coding sequences; white, untranslated sequences). Bottom Linkage disequilibrium structure of polymorphisms across the TNFRSF4 gene region using data from 32 Japanese controls. Haplotype blocks were defined by the solid spine of LD method in Haploview. The number in each cell represents the LD parameter $r^{2}(\times 100)$, blank cells denote $r^{2}=1$. Each cell is painted with graduated color relative to the strength of LD between markers, which is defined by the $r^{2}$ value.

(Fig. 2)

Effect of haplotypes $(a, c)$ and each polymorphism (b, d) on the transcriptional activity of the TNFRSF4 promoter. Relative luciferase activities after transient transfection in COS-7 (a, b) and HEK293 (c, d) cell lines are shown. Activities of the Pr-H1 constructs were considered as 100\%. Each experiment was conducted in triplicate for each sample, and the results are expressed as mean \pm SD for six (COS-7) or five (HEK293) independent experiments. ${ }^{*} P<0.05, * * P<0.01, * * * P<0.001$. 


\section{Supplemental Tables}

(Supplemental Table 1) A total 121 candidate genes for essential hypertention

\begin{tabular}{|c|c|}
\hline Gene name & Gene symbol \\
\hline Acrosin & ACR \\
\hline Adducin-1, alpha & $A D D 1$ \\
\hline Adducin-2, beta & $A D D 2$ \\
\hline Adrenomedullin & $A D M$ \\
\hline Angiopoietin-like 2 & ANGPTL2 \\
\hline Angiotensin converting enzyme 2 & ACE2 \\
\hline Aquaporin-1(proximal) & $A Q P 1$ \\
\hline Aquaporin-2(collecting duct) & $A Q P 2$ \\
\hline Aquaporin-3(collecting duct) & AQP3 \\
\hline Aquaporin-4(medulally collecting duct) & $A Q P 4$ \\
\hline Aquaporin-6(podocyte) & AQP6 \\
\hline Aromatic L-amino acid decarboxylase & $D D C$ \\
\hline ATPase, $\mathrm{H}+$ transporting, lysosomal (vacuolar proton pump), subunit 1 & ATP6AP1 \\
\hline ATPase, $\mathrm{Na}+\mathrm{K}+$ transporting, alpha-1 polypeptide & ATP1A1 \\
\hline Beta-2-adrenergic receptor & $A D R B 2$ \\
\hline Calcium channel, voltage-dependent, $\mathrm{T}$ type, alpha $1 \mathrm{G}$ subunit & CACNA1G \\
\hline Calcium/calmodulin-dependent serine protein kinase & CASK \\
\hline Calpain 10 & CAPN10 \\
\hline Carbonic anhydrase 3 & CA3 \\
\hline Catepsin & CAT \\
\hline CD36 antigen & CD36 \\
\hline CD97 antigen & CD97 \\
\hline CDC-like kinase & CLK1 \\
\hline Chloride channel, kidney, B & CLCNKB \\
\hline Chloride channel-5 & CLCN5 \\
\hline Claudin 4 & CLDN4 \\
\hline Cytochrome c oxidase, subunit VIa, polypeptide 1 & COX6A1 \\
\hline Cytochrome P450, 4a11 & CYP4A11 \\
\hline Death-associated protein kinase 3 & DAPK3 \\
\hline Dopamin receptor D1 & DRD1 \\
\hline Dopamin receptor D1B & $D R D 1 B$ \\
\hline Dopamine receptor D3 & DRD3 \\
\hline Dopamine-beta-hydroxylase & $D B H$ \\
\hline Estrogen receptor 1 & ESR1 \\
\hline
\end{tabular}


FXYD domain-containing ion transport regulator 2

Gap junction protein, beta 2

Glutathione S-transferase, alpha 2 (Yc2)

Glycogen synthase 1

GYS1

Glycogen synthase 2

GYS2

Granzyme B

GZMB

Guanine nucleotide binding protein ( $\mathrm{G}$ protein), gamma transducing

GNGT2 activity polypeptide 2

Heat shock $70 \mathrm{kD}$ protein 5 (glucose-regulated protein, $78 \mathrm{kD}$ )

HSPA5

Hepatoma-derived growth factor, related protein 3

HDGFRP3

Hyaluronidase 1

HYAL1

Hydroxysteroid 11-beta dehydrogenase 1

HSD11B1

Insulin-like growth factor binding protein 5

IGFBP5

Kallikrein 1

KLK1

Kallikrein 13

KLK13

Kallistatin

SERPINA4

Kinesin family member 21B

KIF21B

Kininogen

$K K G$

Kit ligand

KITLG

Latent transforming growth factor beta binding protein 2

LTBP2

Leucine rich repeat (in FLII) interacting protein 1

LRRFIP1

Maternally expressed gene 3

MEG3

Molybdenum cofactor synthesis 2

MOCS2

Natriuretic peptide precursor B

$N P P B$

Natriuretic peptide precursor $\mathrm{C}$

NPR3

Natriuretic peptide receptor A/guanylate cyclase A

NPR1

Natriuretic peptide receptor $\mathrm{C}$

NPR3

Nephrin

NPHN

Nephrocystin

NPHP1

Nitric oxide synthase 3

NOS3

Nuclear receptor subfamily 2, group F, member 6

NR2F6

Parvalbumin

PVALB

Phosphodiesterase 1A, calmodulin-dependent

PDE1A

Placental growth factor

$P G F$

Platelet derived growth factor receptor, beta polypeptide

Potassium inwardly-rectifying channel, subfamily $\mathrm{J}$, member 1 
Potassium inwardly-rectifying channel, subfamily J, member 11

KCNJ11

Potassium inwardly-rectifying channel, subfamily J, member 6

KCNJ6

Potassium large conductance calcium-activated channel, subfamily M,beta

KCNMB1

member 1

Proline-serine-threonine phosphatase-interacting protein 1

PSTPIP1

Prostaglandin E receptor EP4 subtype

PTGER4

Protein $\mathrm{C}$ receptor, endothelial

PROCR

Receptor (calcitonin) activity modifying protein 2

RAMP2

Ribosomal protein S4, X-linked

RPS4X

SAPK/ERK kinase-1

SEK1

Serine/threonine kinase 19

STK19

Serine/threonine kinase 6

AURKA

SFFV proviral integration 1

SPI1

Sodium channel, nonvoltage-gated 1, alpha

SCNN1A

Sodium channel, nonvoltage-gated 1 , beta

SCNN1B

Sodium channel, nonvoltage-gated 1, gamma

SCNN1G

Sodium channel, voltage-gated, type I, delta polypeptide

SCNN1D

Solute carrier family 1 (glial high affinity glutamate transporter),member

SLC1A2

2

Solute carrier family 12 member 1

SLC12A1

Solute carrier family 12 sodium/potassium/chloride transporters)

SLC12A3

Solute carrier family 14 (monocarboxylic acid transporters), member 2

SLC14A2

Solute carrier family 16 , member 1

SLC16A1

Solute carrier family 16 ,member 7

SLC16A7

Solute carrier family 18 (vesicular monoamine), member 1

SLC18A1

Solute carrier family 19 (folate transporter), member 1

SLC19A1

Solute carrier family 21, member 3 (organic anion transporter)

SLCO1A2

Solute carrier family 22 (organic cation transporter), member 1-like

SLC22A1L

Solute carrier family 26 , member 4

SLC26A4

Solute carrier family 4 , anion exchanger, member 1

SLC4A1

(erythrocytemembrane protein band 3, Diego blood group)

Solute carrier family 6 (neurotransmitter transporter,

noradrenalin),member 2

Solute carrier family 8 , member 1 (sodium-calcium exchanger-1)

SLC8A1

Solute carrier family 9 (sodium/hydrogen exchanger), isoform 3

SLC9A3

Solute carrier family 9 (sodium/hydrogen exhanger), isoform 1

SLC9A1

Splicing factor, arginine/serine-rich 5 (SRp40, HRS)

SFRS5

Steroidogenic acute regulatory protein

STAR 
Syntaxin binding protein 1

STXBP1

Synuclein, alpha

SNCA

Thyroid hormone responsive SPOT14 homolog

THRSP

TNF superfamily member 11

TNFSF11

Ttk protein kinase

TTK

TNF receptor superfamily, member $11 \mathrm{~b}$ (osteoprotegerin)

TNFRSF11B

TNF receptor superfamily, member 18

TNFRSF18

TNF receptor superfamily, member 4

TNFRSF4

Uncoupling protein, mitochondrial

UCP1

Vaccinia related kinase 1

VRK1

Vascular endothelial growth factor C

VEGFC

Vesicle-associated membrane protein 3

VAMP3

Villin 2

VIL2

WNK lysine deficient protein kinase 1

PRKWNK1

WNK lysine deficient protein kinase 4

PRKWNK4

WW domain binding protein 1

WBP1 
(Supplemental Table 2) List of genes downregulated in the kidneys of four-copy (Agt 2/2) mice versus one-copy (Agt 0/1) mice

\begin{tabular}{|c|c|c|}
\hline $\begin{array}{l}\text { Accession } \\
\text { Number }\end{array}$ & GeneName & $\begin{array}{l}\text { Fold } \\
\text { change }\end{array}$ \\
\hline AA521869 & steroidogenic acute regulatory protein & -3.1 \\
\hline AI386062 & carbonic anhydrase 3 & -2.5 \\
\hline AA080270 & fatty acid binding protein 4 , adipocyte & -2.4 \\
\hline AA980357 & gelsolin & -1.9 \\
\hline AA458072 & adipocyte complement related protein of $30 \mathrm{kDa}$ & -1.8 \\
\hline W41372 & uncoupling protein, mitochondrial & -1.8 \\
\hline AI120315 & splicing factor, arginine/serine-rich 5 (SRp40, HRS) & -1.6 \\
\hline AA276616 & steroidogenic acute regulatory protein & -1.6 \\
\hline W10293 & androgen regulated vas deferens protein & -1.5 \\
\hline W15725 & $\begin{array}{l}\text { cell death-inducing DNA fragmentation factor, alpha subunit-like } \\
\text { effector A }\end{array}$ & -1.5 \\
\hline AA437572 & inner centromere protein & -1.5 \\
\hline W34620 & kallikrein 26 & -1.5 \\
\hline AI892379 & aminolevulinic acid synthase 1 & -1.4 \\
\hline AA066458 & cadherin 16 & -1.4 \\
\hline AA061218 & DNA segment, Chr 17, human D6S81E 1 & -1.4 \\
\hline AA760070 & esterase 1 & -1.4 \\
\hline AA624690 & fibroblast growth factor regulated protein & -1.4 \\
\hline AA546842 & hypothetical protein MGC7720 & -1.4 \\
\hline AA413767 & interferon regulatory factor 3 & -1.4 \\
\hline AA003609 & ISL1 transcription factor, LIM/homeodomain, (islet-1) & -1.4 \\
\hline W36421 & Moloney leukemia virus 10 & -1.4 \\
\hline AI451780 & prostate specific ets transcription factor & -1.4 \\
\hline AA387891 & RAD1 homolog (S. pombe) & -1.4 \\
\hline AA712003 & resistin like alpha & -1.4 \\
\hline AA244388 & retinoic acid early transcript gamma & -1.4 \\
\hline AA065574 & solute carrier family 12, member 1 & -1.4 \\
\hline AA437805 & SWAP complex protein, $70 \mathrm{kDa}$ & -1.4 \\
\hline AA756672 & thyroid hormone responsive SPOT14 homolog (Rattus) & -1.4 \\
\hline AI553108 & $\begin{array}{l}\text { a disintegrin-like and metalloprotease (reprolysin type) with } \\
\text { thrombospondin type } 1 \text { motif, } 5 \text { (aggrecanase- } 2 \text { ) }\end{array}$ & -1.3 \\
\hline AA413485 & A kinase anchor protein & -1.3 \\
\hline W82672 & aconitase 1 & -1.3 \\
\hline AA606587 & adenylosuccinate lyase & -1.3 \\
\hline
\end{tabular}


AA794074 aldo-keto reductase family 1, member B1 (aldose reductase) -

AI386037 alpha-2-HS-glycoprotein -1.3

AA755981 angiopoietin-like $2 \quad-1.3$

W40608 anterior gradient 2 (Xenepus laevis) -1.3

AI325603 apolipoprotein E -1.3

AA239727 ATP-binding cassette, sub-family B (MDR/TAP), member $1 \quad-1.3$

AA967857 brain protein -1.3

AA546660 calpain $10 \quad-1.3$

AI325851 CD97 antigen -1.3

AA684191 CDC-like kinase -1.3

AI894016 complement component 1, q subcomponent, c polypeptide $\quad-1.3$

AA117547 cyclin D1 -1.3

W12527 cytochrome P450, 2b19 -1.3

AA117605 cytotoxic granule-associated RNA-binding protein $1 \quad-1.3$

W89290 dante -1.3

AI510645 DEAD (aspartate-glutamate-alanine-aspartate) box polypeptide, Y $\quad-1.3$

AI120685 decay accelerating factor $1 \quad-1.3$

AA123152 diacylglycerol acyltransferase -1.3

AA017823 dishevelled 2, dsh homolog (Drosophila) -1.3

AA215144 DNA segment, Chr 16, ERATO Doi 36, expressed -1.3

AA624262 DNA segment, Chr 2, Brigham \& Women's Genetics $0886 \quad-1.3$

AA863502 embryonic stem cell phosphatase -1.3

AA681602 enolase 3, beta muscle -1.3

AI326499 epidermal growth factor -1.3

AI509558 formin-like -1.3

AA177916 fusion 2 (human) -1.3

AA458241 G0/G1 switch gene $2 \quad-1.3$

AI386181 gamma-glutamyl carboxylase $\quad-1.3$

AA930013 gasdermin -1.3

AI385860 GLI-Kruppel family member GLI $\quad-1.3$

AI325384 glucokinase activity -1.3

AI326575 glucose-6-phosphatase, catalytic -1.3

AI154009 guanine nucleotide binding protein ( $\mathrm{G}$ protein), gamma -1.3

AA450922 heat shock 70kD protein 5 (glucose-regulated protein, 78kD) -1.3

AI661389 hepatoma-derived growth factor, related protein $3 \quad-1.3$ 
AA473972 heterogeneous nuclear ribonucleoprotein H1

AA688635 hyaluronidase $1 \quad-1.3$

AI789916 hydroxysteroid 11-beta dehydrogenase $1 \quad-1.3$

AA432994 hypothetical protein, MNCb-2032 -1.3

W15610 integrin beta $4 \quad-1.3$

AI430631 just another zinc finger protein -1.3

AA760344 keratin complex 1, acidic, gene $15 \quad-1.3$

AI645902 kinesin family member 21B -1.3

AI099009 latent transforming growth factor beta binding protein $2 \quad-1.3$

AI614021 leucine rich repeat (in FLII) interacting protein $1 \quad-1.3$

W97303 maternally expressed gene $3 \quad-1.3$

W34188 Moloney leukemia virus $10 \quad-1.3$

AI592114 molybdenum cofactor synthesis $2 \quad-1.3$

AI036466 Mus musculus adult male testis cDNA, RIKEN full-length $\quad-1.3$

AA611779 Mus musculus adult male xiphoid cartilage cDNA, RIKEN $\quad-1.3$

full-length enriched library, clone:5230400J22, full insert

sequence

AA672784 Mus musculus mRNA for erythroid differentiation regulator, $\quad-1.3$ partial

AA606711 myeloid-associated differentiation marker -1.3

AA276726 natural killer cell BY55 precursor -1.3

AA619774 next to the Brcal -1.3

AA512708 nitric oxide synthase 2, inducible, macrophage -1.3

AA517353 nuclear factor of kappa light chain gene enhancer in B-cells $\quad-1.3$

AI117296 Paneth cell enhanced expression $\quad-1.3$

AA106128 phosphoenolpyruvate carboxykinase 1, cytosolic -1.3

AI327450 phospholipase A2, group IB, pancreas -1.3

AA271866 phospholipase A2, group VI -1.3

AA982549 placental growth factor -1.3

AA624552 platelet derived growth factor receptor, beta polypeptide -1.3

AA517595 polymerase (DNA directed), delta 2, regulatory subunit (50 kDa) $\quad-1.3$

AA466979 pre B-cell leukemia transcription factor $1 \quad-1.3$

AI326527 preproacrosin -1.3

AA980931 proline-serine-threonine phosphatase-interacting protein $1 \quad-1.3$

AA016910 protein $\mathrm{C}$ receptor, endothelial -1.3

AA221322 protein tyrosine phosphatase, non-receptor type $5 \quad-1.3$ 
AA051479 Public domain EST $\quad-1.3$

AI614454 reduced in osteosclerosis transporter -1.3

AA681171 RNA polymerase 1-2 (128 kDa subunit) -1.3

AA238294 sema domain, immunoglobulin domain (Ig), transmembrane $\quad-1.3$

domain (TM) and short cytoplasmic domain, (semaphorin) 4G

AI605734 septin $3 \quad-1.3$

AI180767 serine/threonine kinase $19 \quad-1.3$

W47914 sialyltransferase 8 (alpha-2, 8-sialytransferase) B $\quad-1.3$

AI120278 solute carrier family 16 (monocarboxylic acid transporters), $\quad-1.3$ member 2

AA066386 solute carrier family 22 (organic cation transporter), member 1-like $\quad-1.3$

AI156032 solute carrier family 26, member $4 \quad-1.3$

AI894071 sparc/osteonectin, cwcv and kazal-like domains proteoglycan $1 \quad-1.3$

AA414787 t-complex testis-expressed $3 \quad-1.3$

AI466119 transducin-like enhancer of split 2, homolog of Drosophila E(spl) $\quad-1.3$

AI385796 transketolase -1.3

AA274169 tumor necrosis factor receptor superfamily, member $18 \quad-1.3$

AI323199 tumor necrosis factor receptor superfamily, member $4 \quad-1.3$

AW210120 vesicle-associated membrane protein $3 \quad-1.3$

AA066685 villin $2 \quad-1.3$

W53568 WW domain binding protein $1 \quad-1.3$ 
(Supplemental Table 3) List of genes upregulated in the kidneys of four-copy (Agt 2/2) mice versus one-copy (Agt 0/1) mice

\begin{tabular}{|c|c|c|}
\hline $\begin{array}{l}\text { Accession } \\
\text { Number }\end{array}$ & GeneName & $\begin{array}{l}\text { Fold } \\
\text { change }\end{array}$ \\
\hline AA498760 & syntaxin binding protein 1 & 1.9 \\
\hline AA638765 & metallothionein 1 & 1.8 \\
\hline W15809 & hemoglobin, beta adult major chain & 1.7 \\
\hline W36474 & metallothionein 2 & 1.7 \\
\hline AA517682 & repeat family 3 gene & 1.7 \\
\hline AA106071 & hemoglobin, beta adult major chain & 1.6 \\
\hline AA066763 & hemoglobin, beta adult major chain & 1.6 \\
\hline AA183239 & insulin-like growth factor binding protein 5 & 1.5 \\
\hline AA106365 & cytochrome P450, 4a14 & 1.5 \\
\hline AI182724 & $\begin{array}{l}\text { suppressor of initiator codon mutations, related sequence } 1 \text { (S. } \\
\text { cerevisiae) }\end{array}$ & 1.5 \\
\hline AI481911 & IG ALPHA CHAIN C REGION & 1.5 \\
\hline AA432457 & $\begin{array}{l}\text { ELAV (embryonic lethal, abnormal vision, Drosophila)-like } 2 \text { (Hu } \\
\text { antigen B) }\end{array}$ & 1.5 \\
\hline AI892243 & ferritin heavy chain & 1.5 \\
\hline AI553078 & CD36 antigen & 1.5 \\
\hline W08923 & cytochrome c oxidase, subunit VI a, polypeptide 1 & 1.5 \\
\hline AA108723 & FXYD domain-containing ion transport regulator 2 & 1.5 \\
\hline AA763351 & death-associated kinase 3 & 1.4 \\
\hline AA273270 & ribosomal protein $\mathrm{S} 4, \mathrm{X}$-linked & 1.4 \\
\hline AA244820 & retinol dehydrogenase type 6 & 1.4 \\
\hline AI390326 & ribosomal protein $\mathrm{S} 6$ & 1.4 \\
\hline AA003877 & nel-like 2 homolog (chicken) & 1.4 \\
\hline AA461886 & $\begin{array}{l}\text { tumor necrosis factor receptor superfamily, member } 11 \mathrm{~b} \\
\text { (osteoprotegerin) }\end{array}$ & 1.4 \\
\hline $\mathrm{AI} 048040$ & claudin 4 & 1.4 \\
\hline AI604245 & protocadherin 7 & 1.4 \\
\hline AI642307 & ribosomal protein S11 & 1.4 \\
\hline AA065880 & nuclear factor I/B & 1.4 \\
\hline AA106894 & carbonic anhydrase 4 & 1.4 \\
\hline AA067971 & ral guanine nucleotide dissociation stimulator & 1.4 \\
\hline AA066072 & phosphatidylcholine transfer protein & 1.4 \\
\hline AA709984 & RAB17, member RAS oncogene family & 1.4 \\
\hline AA619950 & cyclin I & 1.4 \\
\hline
\end{tabular}


AA437994 baculoviral IAP repeat-containing 4 1.4

AA414425 translocase of inner mitochondrial membrane 23 homolog (yeast) 1.4

AA146478 IG ALPHA CHAIN C REGION 1.4

AA606908 ring finger protein $10 \quad 1.4$

AA544212 cellular repressor of E1A-stimulated genes $\quad 1.4$

AA727017 immediate early response 2 1.4

AA596753 latexin 1.4

AA469630 choline kinase 1.4

AA265490 bone morphogenetic protein receptor, type 1A 1.4

AA183318 ATPase, $\mathrm{H}+$ transporting, lysosomal (vacuolar proton pump), $\quad 1.4$

AA624897 ribosomal protein S16 1.4

AA795558 Ttk protein kinase $\quad 1.4$

AA673731 chitinase 3-like 3 1.4

$\begin{array}{lll}\text { AI510034 synuclein, alpha } & 1.4\end{array}$

AI892747 glutathione S-transferase, alpha 2(Yc2) 1.4

AA450910 brachyury 1.4

AI597531 gap junction membrane channel protein beta $2 \quad 1.4$

AA474223 centrin 2 1.4

AI550227 Mus musculus unknown protein mRNA, partial cds $\quad 1.4$

AI390129 proteasome (prosome, macropain) subunit, alpha type 2 1.3

$\begin{array}{lll}\text { AA027530 placental lactogen } 2 & 1.3\end{array}$

AI020130 granzyme B 1.3

AA675376 DNA segment, Chr 7, ERATO Doi 373, expressed 1.3

AA674571 radixin 1.3

AI552258 reversion-inducing-cysteine-rich protein with kazal motifs $\quad 1.3$

AA423123 histocompatibility 2, T region locus $17 \quad 1.3$

AA290362 origin recognition complex, subunit 5 homolog (S. cerevisiae) 1.3

AI390207 calcium/calmodulin-dependent serine protein kinase 1.3

AA221832 four jointed box 1 (Drosophila) 1.3

AI390473 T-cell acute lymphocytic leukemia 1 1.3

AA230517 retinoic acid receptor, gamma 1.3

$\begin{array}{lll}\text { AA182058 } & \text { zinc finger protein } 318 & 1.3\end{array}$

$\begin{array}{lll}\text { AA189288 etoile } & 1.3\end{array}$

AI324355 mesenchyme homeobox $2 \quad 1.3$

$\begin{array}{lll}\text { AA014972 granzyme F } & 1.3\end{array}$

AA165899 LIM-domain containing, protein kinase $\quad 1.3$

W17640 aplysia ras-related homolog D (RhoD) 1.3 
W16027 phosphodiesterase 1A, calmodulin-dependent $\quad 1.3$

W14436 matrix metalloproteinase 9 1.3

AA174428 Unc-51 like kinase 2 (C. elegans) 1.3

AA067153 platelet-activating factor acetylhydrolase, isoform 1b, beta1 1.3

AA104976 staufen (RNA-binding protein) homolog 2 (Drosophila) 1.3

AA666910 membrane protein, palmitoylated 6 (MAGUK p55 subfamily 1.3 member 6)

AA617414 nucleosome binding protein 1 1.3

AA763056 suppressor of clear, C. elegans, homolog of 1.3

AA798766 selectin, lymphocyte 1.3

AA716921 Mus musculus adult male testis cDNA, RIKEN full-length 1.3

AA645995 TG interacting factor $\quad 1.3$

AA755273 protein related to DAC and cerberus 1.3

AA672766 Mouse mRNA for TI-227 1.3

AI385493 crystallin, gamma B $\quad 1.3$

AA570965 Mouse complement factor H-related protein mRNA, complete cds, $\quad 1.3$

AI385457 retinol binding protein 2, cellular $\quad 1.3$

AI323047 splicing factor 3a, subunit 2, 66kD $\quad 1.3$

AA671019 procollagen, type IX, alpha $3 \quad 1.3$

AI549654 programmed cell death $10 \quad 1.3$

AA210568 DNA methyltransferase 3B $\quad 1.3$

AA438152 guanine nucleotide binding protein, alpha inhibiting $3 \quad 1.3$

AA212042 RAB9, member RAS oncogene family 1.3

AA450855 peroxiredoxin 5 1.3

AA437837 core binding factor beta 1.3

AI550200 SEC61, alpha subunit 2 (S. cerevisiae) 1.3

AI121593 X-linked myotubular myopathy gene 1 1.3

AI390848 aplysia ras-related homolog G (RhoG) 1.3

$\begin{array}{lll}\text { AI120332 ribosomal protein L41 } & 1.3\end{array}$

AI159330 globin inducing factor, fetal 1.3

W13748 ribosomal protein L12 1.3

AI158823 immunoglobulin heavy chain 3 (serum IgG2b) 1.3

$\begin{array}{lll}\text { AI156457 cytochrome P450, 7b1 } & 1.3\end{array}$

AI158565 guanine nucleotide binding protein (G protein), gamma $10 \quad 1.3$

$\begin{array}{lll}\text { AA771678 protein kinase, cGMP-dependent, type II } & 1.3\end{array}$ 
AI550872 RAB11a, member RAS oncogene family $\quad 1.3$

AA510654 SEC22 vesicle trafficking protein-like 1 (S. cerevisiae) 1.3

AA497627 intersectin (SH3 domain protein 1A) 1.3

$\begin{array}{lll}\text { AA466550 } & \text { poliovirus receptor-related } 3 & 1.3\end{array}$

AA415862 SRY-box containing gene 2 1.3

$\begin{array}{ll}\text { W35084 hematopoietic zinc finger } & 1.3\end{array}$

AA474336 synaptonemal complex protein $3 \quad 1.3$

AA414670 mitogen activated protein kinase kinase $4 \quad 1.3$

AA437876 degenerative spermatocyte homolog (Drosophila) 1.3

AA437878 Rho-associated coiled-coil forming kinase $1 \quad 1.3$

$\begin{array}{lll}\text { AA444231 ribosomal protein S5 } & 1.3\end{array}$

AA259281 LIM homeobox protein 2 1.3

AA245183 mab-21-like 2(C. elegans) 1.3

AA161823 lymphocyte antigen $116 \quad 1.3$

$\begin{array}{lll}\text { AA671424 fibroblast growth factor inducible } 14 & 1.3\end{array}$

AA638960 casein alpha $\quad 1.3$

AA178447 plexin 6 1.3

$\begin{array}{lll}\text { AA562552 glutathione peroxidase 1 } & 1.3\end{array}$

$\begin{array}{lll}\text { AA543948 phosphatidylcholine transfer protein-like } & 1.3\end{array}$

AA474438 profilin 2 1.3

AA880295 immunoglobulin joining chain 1.3

AI536384 differential display and activated by p53 1.3

$\begin{array}{lll}\text { AI390811 glutamine fructose-6-phosphate transaminase 2 } & 1.3\end{array}$

AA726944 vascular endothelial growth factor C 1.3

$\begin{array}{lll}\text { AA727051 myeloid leukemia factor } 1 & 1.3\end{array}$

AA866934 vesicle transport through interaction with t-SNAREs 1b homolog $\quad 1.3$

AA596456 prostaglandin E receptor EP4 subtype 1.3

AA596742 testis derived transcript $\quad 1.3$

AA068464 ect2 oncogene 1.3

AA068624 hydroxyacid oxidase (glycolate oxidase) $3 \quad 1.3$

AA065684 helicase, lymphoid specific 1.3

AI326554 aldo-keto reductase family 1, member C1 (aldehyde reductase) $\quad 1.3$

$\begin{array}{lll}\text { AA066598 Kruppel-like factor } 9 & 1.3\end{array}$

$\begin{array}{lll}\text { AI597336 tripartite motif protein TRIM2 } & 1.3\end{array}$

AA450785 Y box protein 1 1.3

$\begin{array}{lll}\text { AI390104 destrin } & 1.3\end{array}$

$\begin{array}{lll}\text { W16222 septin } 1 & 1.3\end{array}$

W16059 glutathione S-transferase like $\quad 1.3$ 
AA967493 mitogen activated protein kinase kinase kinase $7 \quad 1.3$

AA473417 cytochrome b-245, alpha polypeptide 1.3

AA237845 coagulation factor XIII, beta subunit 1.3

AA250679 aldo-keto reductase AKR1C12 1.3

AA239479 hydroxyacid oxidase 1, liver $\quad 1.3$

AA270885 parvalbumin 1.3

AA198237 nuclear receptor subfamily 2, group F, member $6 \quad 1.3$

$\begin{array}{lll}\text { AI644821 vaccinia related kinase } 1 & 1.3\end{array}$

AA220400 integrin binding sialoprotein $\quad 1.3$

AI893749 serine/threonine kinase $6 \quad 1.3$

AA118767 guanine nucleotide binding protein (G protein), gamma $12 \quad 1.3$

AI893970 platelet derived growth factor, alpha $\quad 1.3$

AA118183 origin of replication 3 homolog (S. cerevisiae) 1.3

AA114742 Mus musculus E-cadherin binding protein E7 mRNA, complete $\quad 1.3$ cds

W89951 insulin-like growth factor binding protein $3 \quad 1.3$

AA833460 histocompatibility-2 complex class 1-like sequence 1.3

AA739464 killer cell lectin-like receptor, subfamily A, member $3 \quad 1.3$

$\begin{array}{lll}\text { AI893936 hepatic nuclear factor } 4 & 1.3\end{array}$

AA870247 mitogen regulated protein, proliferin $3 \quad 1.3$

AA546971 membrane-spanning 4-domains, subfamily A, member $2 \quad 1.3$

AA267725 DNA segment, Chr 1, ERATO Doi 622, expressed 1.3

AA198236 kit ligand 1.3

AA254942 carbonic anhydrase-like sequence 1 1.3

$\begin{array}{lll}\text { AA239990 SFFV proviral integration } 1 & 1.3\end{array}$

AA242256 zinc finger protein of the cerebellum $1 \quad 1.3$

AI509951 calcium channel, voltage-dependent, T type, alpha 1G subunit $\quad 1.3$

AW209707 hemoglobin Z, beta-like embryonic chain 1.3

$\begin{array}{lll}\text { AA623561 retinoblastoma binding protein } 4 & 1.3\end{array}$

AA623498 X-linked lymphocyte-regulated complex 1.3

AA624429 mannosidase 1, beta 1.3

AA624421 cornichon homolog (Drosophila) 1.3

AA607085 polymerase, gamma 1.3

$\begin{array}{lll}\text { AA606561 PFTAIRE protein kinase } 1 & 1.3\end{array}$

AI594243 CD8beta opposite strand 1.3

AA606973 ribosomal protein, mitochondrial, L7 1.3

AA575501 calmodulin 2 1.3

AA437942 cytokine inducible SH2-containing protein $1 \quad 1.3$ 
AA517509 transcription factor Dp $1 \quad 1.3$

AI596527 ribosomal protein L26 1.3

AA981355 Mus musculus DNA cytosine methyltransferase mRNA 1.3

$\begin{array}{lll}\text { AI324371 interleukin } 4 & 1.3\end{array}$

AA655648 neuronal protein 15.6 1.3

$\begin{array}{lll}\text { AA717170 } & \text { BCR downstream signaling } 1 & 1.3\end{array}$

AA795621 lymphocyte antigen $84 \quad 1.3$

AA822050 NAD(P) dependent steroid dehydrogenase-like $\quad 1.3$

$\begin{array}{lll}\text { AI323028 thymidylate synthase } & 1.3\end{array}$

$\begin{array}{lll}\text { AI552765 S-adenosylmethionine decarboxylase 1 } & 1.3\end{array}$

AI386059 acidic ribosomal phosphoprotein PO 1.3

$\begin{array}{lll}\text { AA080175 claudin } 8 & 1.3\end{array}$

$\begin{array}{lll}\text { AA080181 myelin protein zero } & 1.3\end{array}$

AI326538 integrin, alpha E, epithelial-associated 1.3

AI595008 Sin3-associated polypeptide $18 \quad 1.3$ 
(Supplemental Table 4) Genotyped SNPs and $P$ values for overall distribution of haplotypes in initial screening of candidate genes

\begin{tabular}{|c|c|c|c|c|c|}
\hline Gene name & $\begin{array}{l}\text { Gene } \\
\text { symbol }\end{array}$ & $\mathrm{SNP} \mathrm{ID}^{\mathrm{a}}$ & $\begin{array}{l}\text { Male }+ \\
\text { Female } \\
P \text { value }^{\text {b }}\end{array}$ & $\begin{array}{l}\text { Male } \\
P \\
\text { value }^{\mathrm{b}}\end{array}$ & $\begin{array}{l}\text { Female } \\
P \\
\text { value }^{\text {b }}\end{array}$ \\
\hline Acrosin & $A C R$ & IMS-JST33261 & 0.667 & 0.651 & 1.000 \\
\hline \multirow[t]{2}{*}{ Adducin-1, alpha } & \multirow[t]{2}{*}{$A D D 1$} & IMS-JST032023 & \multirow[t]{2}{*}{0.554} & \multirow[t]{2}{*}{0.20} & \multirow[t]{2}{*}{0.506} \\
\hline & & IMS-JST005769 & & & \\
\hline \multirow[t]{4}{*}{ Adducin-2, beta } & \multirow[t]{4}{*}{$A D D 2$} & IMS-JST126484 & \multirow[t]{4}{*}{0.53} & \multirow[t]{4}{*}{0.387} & \multirow[t]{4}{*}{0.135} \\
\hline & & IMS-JST108417 & & & \\
\hline & & IMS-JST024418 & & & \\
\hline & & IMS-JST024420 & & & \\
\hline \multirow[t]{2}{*}{ Angiopoietin-like 2} & \multirow[t]{2}{*}{ ANGPTL2 } & rs1281157 & \multirow[t]{2}{*}{0.131} & \multirow[t]{2}{*}{0.062} & \multirow[t]{2}{*}{0.138} \\
\hline & & IMS-JST052573 & & & \\
\hline \multirow[t]{5}{*}{ Aquaporin-1 (proximal) } & \multirow[t]{5}{*}{$A Q P 1$} & IMS-JST003211 & \multirow[t]{5}{*}{0.311} & \multirow[t]{5}{*}{0.455} & \multirow[t]{5}{*}{0.090} \\
\hline & & IMS-JST003212 & & & \\
\hline & & IMS-JST021256 & & & \\
\hline & & IMS-JST008162 & & & \\
\hline & & IMS-JST008162 & & & \\
\hline \multirow{4}{*}{$\begin{array}{l}\text { Aquaporin-2 (collecting } \\
\text { duct) }\end{array}$} & \multirow{4}{*}{$A Q P 2$} & IMS-JST138705 & \multirow[t]{4}{*}{ 0.038* } & \multirow[t]{4}{*}{0.4} & \multirow[t]{4}{*}{0.081} \\
\hline & & IMS-JST092583 & & & \\
\hline & & IMS-JST138708 & & & \\
\hline & & IMS-JST138709 & & & \\
\hline \multirow{4}{*}{$\begin{array}{l}\text { Aquaporin-3 (collecting } \\
\text { duct) }\end{array}$} & \multirow[t]{4}{*}{$A Q P 3$} & IMS-JST111570 & \multirow[t]{4}{*}{0.980} & \multirow[t]{4}{*}{0.970} & \multirow[t]{4}{*}{0.931} \\
\hline & & IMS-JST111570 & & & \\
\hline & & IMS-JST111569 & & & \\
\hline & & IMS-JST016827 & & & \\
\hline Aquaporin-4 (medulally & $A Q P 4$ & IMS-JST116766 & 0.108 & 0.634 & 0.984 \\
\hline collecting duct) & & IMS-JST116767 & & & \\
\hline & & IMS-JST116771 & & & \\
\hline & & IMS-JST003213 & & & \\
\hline & & IMS-JST003214 & & & \\
\hline & & IMS-JST116776 & & & \\
\hline Aromatic L-amino acid & $D D C$ & rs2044859 & 0.818 & 0.971 & 0.323 \\
\hline decarboxylase & & rs1470750 & & & \\
\hline & & rs2060761 & & & \\
\hline ATPase, $\mathrm{H}+$ transporting, & ATP6AP1 & IMS-JST082807 & 0.265 & 0.119 & 0.391 \\
\hline
\end{tabular}


lysosomal (vacuolar

proton pump), subunit 1

\begin{tabular}{|c|c|c|c|c|c|}
\hline $\begin{array}{l}\text { Beta-2-adrenergic } \\
\text { receptor }\end{array}$ & $A D R B 2$ & $\begin{array}{l}\text { IMS-JST087866 } \\
\text { IMS-JST132959 } \\
\text { IMS-JST132960 }\end{array}$ & 0.91 & 0.948 & 0.208 \\
\hline $\begin{array}{l}\text { Calcium channel, } \\
\text { voltage-dependent, T } \\
\text { type, alpha } 1 \mathrm{G} \text { subunit }\end{array}$ & CACNA1G & $\begin{array}{l}\text { IMS-JST011704 } \\
\text { IMS-JST095890 }\end{array}$ & 0.359 & 0.504 & 0.519 \\
\hline Calpain 10 & CAPN10 & $\begin{array}{l}\text { IMS-JST149659 } \\
\text { IMS-JST100982 }\end{array}$ & 0.762 & 0.987 & 0.072 \\
\hline Carbonic anhydrase 3 & CA3 & $\begin{array}{l}\text { IMS-JST111349 } \\
\text { IMS-JST111350 } \\
\text { IMS-JST111351 } \\
\text { IMS-JST111352 } \\
\text { IMS-JST064895 }\end{array}$ & 0.75 & 0.884 & 0.13 \\
\hline Catepsin & CAT & $\begin{array}{l}\text { IMS-JST055760 } \\
\text { IMS-JST009272 } \\
\text { IMS-JST009271 }\end{array}$ & 0.615 & 0.466 & 0.968 \\
\hline CD36 antigen & CD36 & IMS-JST005702 & 0.332 & 0.901 & 0.086 \\
\hline CD97 antigen & CD97 & $\begin{array}{l}\text { IMS-JST059524 } \\
\text { IMS-JST059522 }\end{array}$ & 0.856 & 0.781 & 0.557 \\
\hline $\begin{array}{l}\text { Chloride channel, kidney, } \\
\text { B }\end{array}$ & CLCNKB & IMS-JST052374 & 0.947 & 0.521 & 0.080 \\
\hline Dopamine receptor D3 & $D R D 3$ & $\begin{array}{l}\text { rs1385884 } \\
\text { rs1872575 }\end{array}$ & 0.257 & 0.240 & 0.428 \\
\hline $\begin{array}{l}\text { Dopamine-beta-hydroxyla } \\
\text { se }\end{array}$ & $D B H$ & $\begin{array}{l}\text { IMS-JST090738 } \\
\text { IMS-JST000449 }\end{array}$ & 0.920 & 0.296 & 0.083 \\
\hline Estrogen receptor 2 & ESR2 & $\begin{array}{l}\text { IMS-JST051491 } \\
\text { IMS-JST051808 } \\
\text { IMS-JST030988 } \\
\text { IMS-JST030987 }\end{array}$ & $0.016 *$ & 0.018* & 0.415 \\
\hline $\begin{array}{l}\text { FXYD domain-containing } \\
\text { ion transport regulator } 2\end{array}$ & FXYD2 & $\begin{array}{l}\text { IMS-JST053456 } \\
\text { IMS-JST072429 }\end{array}$ & 0.135 & 0.107 & 0.616 \\
\hline Glycogen synthase 1 & GYS1 & $\begin{array}{l}\text { IMS-JST065629 } \\
\text { IMS-JST097169 }\end{array}$ & 0.021* & 0.127 & 0.071 \\
\hline Granzyme B & $G Z M B$ & IMS-JST069533 & 0.679 & 0.902 & 0.083 \\
\hline
\end{tabular}


IMS-JST069532

IMS-JST016601

\begin{tabular}{|c|c|c|c|c|c|}
\hline $\begin{array}{l}\text { Guanine nucleotide } \\
\text { binding protein ( } \mathrm{G} \\
\text { protein), gamma } \\
\text { transducing activity } \\
\text { polypeptide } 2\end{array}$ & GNGT2 & $\begin{array}{l}\text { rs634370 } \\
\text { rs850526 }\end{array}$ & 0.343 & 0.504 & 0.236 \\
\hline $\begin{array}{l}\text { Heat shock } 70 \mathrm{kD} \text { protein } \\
5 \text { (glucose-regulated } \\
\text { protein, } 78 \mathrm{kD})\end{array}$ & HSPA5 & IMS-JST119759 & 0.08 & 0.104 & 0.597 \\
\hline $\begin{array}{l}\text { Hydroxysteroid 11-beta } \\
\text { dehydrogenase } 1\end{array}$ & HSD11B1 & $\begin{array}{l}\text { IMS-JST017377 } \\
\text { IMS-JST031982 } \\
\text { IMS-JST031983 } \\
\text { IMS-JST017380 } \\
\text { IMS-JST017380 }\end{array}$ & 0.495 & 0.881 & 0.201 \\
\hline $\begin{array}{l}\text { Insulin-like growth factor } \\
\text { binding protein } 5\end{array}$ & IGFBP5 & $\begin{array}{l}\text { IMS-JST012990 } \\
\text { IMS-JST108187 } \\
\text { IMS-JST012991 }\end{array}$ & 0.126 & 0.119 & 0.688 \\
\hline Kallikrein 1 & $K L K 1$ & $\begin{array}{l}\text { IMS-JST060444 } \\
\text { IMS-JST179918 }\end{array}$ & 0.084 & 0.449 & $0.029 *$ \\
\hline Kallistatin & SERPINA4 & $\begin{array}{l}\text { IMS-JST115784 } \\
\text { IMS-JST005765 } \\
\text { IMS-JST005765 }\end{array}$ & 0.571 & 0.663 & 0.375 \\
\hline Kininogen & $K K G$ & $\begin{array}{l}\text { IMS-JST061447 } \\
\text { IMS-JST061448 } \\
\text { IMS-JST061450 }\end{array}$ & 0.432 & 0.61 & 0.069 \\
\hline Kit ligand & KITLG & $\begin{array}{l}\text { IMS-JST138554 } \\
\text { IMS-JST138552 }\end{array}$ & 0.192 & 0.086 & 0.792 \\
\hline $\begin{array}{l}\text { Latent transforming } \\
\text { growth factor beta binding } \\
\text { protein } 2\end{array}$ & LTBP2 & $\begin{array}{l}\text { IMS-JST093976 } \\
\text { IMS-JST093978 } \\
\text { IMS-JST093979 } \\
\text { IMS-JST093980 }\end{array}$ & 0.123 & 0.828 & 0.075 \\
\hline $\begin{array}{l}\text { Maternally expressed } \\
\text { gene } 3\end{array}$ & MEG3 & $\begin{array}{l}\text { IMS-JST139888 } \\
\text { IMS-JST139889 }\end{array}$ & 0.415 & 0.341 & 0.776 \\
\hline $\begin{array}{l}\text { Natriuretic peptide } \\
\text { precursor C }\end{array}$ & $N P R 3$ & $\begin{array}{l}\text { IMS-JST150214 } \\
\text { IMS-JST150204 }\end{array}$ & 0.131 & 0.062 & 0.234 \\
\hline Nephrin & NPHN & $\begin{array}{l}\text { IMS-JST175323 } \\
\text { IMS-JST000541 }\end{array}$ & 0.078 & $0.048 *$ & 0.148 \\
\hline
\end{tabular}




\begin{tabular}{|c|c|c|c|c|c|}
\hline Nephrocystin & NPHP1 & IMS-JST066065 & 0.055 & 0.093 & 0.421 \\
\hline \multirow[t]{2}{*}{ Nitric oxide synthase 3} & NOS3 & IMS-JST117271 & 0.181 & 0.313 & 0.281 \\
\hline & & IMS-JST117269 & & & \\
\hline \multirow[t]{3}{*}{ Parvalbumin } & PVALB & IMS-JST033721 & 0.361 & 0.399 & 0.374 \\
\hline & & IMS-JST033718 & & & \\
\hline & & IMS-JST033714 & & & \\
\hline \multirow[t]{2}{*}{ Placental growth factor } & $P G F$ & IMS-JST139888 & 0.415 & 0.341 & 0.776 \\
\hline & & IMS-JST139889 & & & \\
\hline \multirow{4}{*}{$\begin{array}{l}\text { Platelet derived growth } \\
\text { factor receptor, beta } \\
\text { polypeptide }\end{array}$} & PDGFRB & IMS-JST109456 & 0.079 & 0.070 & 0.428 \\
\hline & & IMS-JST109453 & & & \\
\hline & & IMS-JST012450 & & & \\
\hline & & IMS-JST087370 & & & \\
\hline \multirow{3}{*}{$\begin{array}{l}\text { Potassium } \\
\text { inwardly-rectifying } \\
\text { channel, subfamily J, } \\
\text { member } 6\end{array}$} & KCNJ6 & IMS-JST144710 & 0.083 & 0.065 & 0.081 \\
\hline & & IMS-JST144706 & & & \\
\hline & & IMS-JST144687 & & & \\
\hline \multirow{5}{*}{$\begin{array}{l}\text { Potassium large } \\
\text { conductance } \\
\text { calcium-activated } \\
\text { channel, subfamily M,beta } \\
\text { member } 1\end{array}$} & KCNMB1 & IMS-JST006470 & 0.19 & 0.111 & 0.983 \\
\hline & & IMS-JST057105 & & & \\
\hline & & & & & \\
\hline & & & & & \\
\hline & & & & & \\
\hline $\begin{array}{l}\text { Protein C receptor, } \\
\text { endothelial }\end{array}$ & PROCR & IMS-JST047041 & 0.445 & 0.731 & 0.132 \\
\hline \multirow[t]{4}{*}{ Serine/threonine kinase 19} & STK19 & rs474534 & 0.168 & 0.522 & 0.193 \\
\hline & & IMS-JST033921 & & & \\
\hline & & rs377370 & & & \\
\hline & & rs389883 & & & \\
\hline \multirow[t]{2}{*}{ Serine/threonine kinase 6} & $A U R K A$ & IMS-JST114769 & 0.615 & 0.818 & 0.156 \\
\hline & & IMS-JST144216 & & & \\
\hline \multirow{3}{*}{$\begin{array}{l}\text { Sodium channel, } \\
\text { nonvoltage-gated 1, alpha }\end{array}$} & SCNN1A & IMS-JST006608 & 0.571 & 0.663 & 0.375 \\
\hline & & IMS-JST092986 & & & \\
\hline & & IMS-JST092985 & & & \\
\hline \multirow{4}{*}{$\begin{array}{l}\text { Sodium channel, } \\
\text { nonvoltage-gated } 1 \text {, beta }\end{array}$} & SCNN1B & IMS-JST059724 & 0.561 & 0.81 & 0.305 \\
\hline & & IMS-JST059723 & & & \\
\hline & & IMS-JST059722 & & & \\
\hline & & IMS-JST095265 & & & \\
\hline \multirow{2}{*}{$\begin{array}{l}\text { Solute carrier family } 1 \\
\text { (glial high affinity }\end{array}$} & SLC1A2 & IMS-JST069326 & $0.017 *$ & $0.04 *$ & $0.014^{*}$ \\
\hline & & IMS-JST069329 & & & \\
\hline
\end{tabular}




\begin{tabular}{|c|c|c|c|c|c|}
\hline $\begin{array}{l}\text { glutamate transporter), } \\
\text { member } 2\end{array}$ & & IMS-JST117720 & & & \\
\hline $\begin{array}{l}\text { Solute carrier family } 12 \\
\text { member } 1\end{array}$ & SLC12A1 & $\begin{array}{l}\text { IMS-JST027033 } \\
\text { IMS-JST027035 } \\
\text { IMS-JST043660 }\end{array}$ & 0.124 & 0.338 & 0.471 \\
\hline $\begin{array}{l}\text { Solute carrier family } 12 \\
\text { sodium/potassium/chlorid } \\
\text { e transporters) }\end{array}$ & SLC12A3 & IMS-JST040573 & 0.487 & 0.354 & 0.883 \\
\hline $\begin{array}{l}\text { Solute carrier family } 14 \\
\text { (monocarboxylic acid } \\
\text { transporters), member } 2\end{array}$ & $S L C 14 A 2$ & $\begin{array}{l}\text { IMS-JST082696 } \\
\text { IMS-JST143078 } \\
\text { IMS-JST072854 }\end{array}$ & 0.409 & 0.247 & 0.06 \\
\hline $\begin{array}{l}\text { Solute carrier family } 18 \\
\text { (vesicular monoamine), } \\
\text { member } 1\end{array}$ & SLC18A1 & $\begin{array}{l}\text { IMS-JST111224 } \\
\text { IMS-JST065233 } \\
\text { IMS-JST065231 }\end{array}$ & 0.099 & 0.143 & 0.522 \\
\hline $\begin{array}{l}\text { Solute carrier family } 22 \\
\text { (organic cation } \\
\text { transporter), member } \\
\text { 1-like }\end{array}$ & SLC22A1L & $\begin{array}{l}\text { IMS-JST018612 } \\
\text { IMS-JST018613 } \\
\text { IMS-JST058628 } \\
\text { IMS-JST037271 }\end{array}$ & 0.097 & 0.168 & 0.355 \\
\hline $\begin{array}{l}\text { Solute carrier family } 26 \text {, } \\
\text { member } 4\end{array}$ & SLC26A4 & $\begin{array}{l}\text { IMS-JST046871 } \\
\text { IMS-JST046872 } \\
\text { IMS-JST089508 } \\
\text { IMS-JST007917 }\end{array}$ & 0.628 & 0.844 & 0.312 \\
\hline $\begin{array}{l}\text { Solute carrier family } 4 \text {, } \\
\text { anion exchanger, member } \\
1 \text { (erythrocytemembrane } \\
\text { protein band } 3 \text {, Diego } \\
\text { blood group) }\end{array}$ & SLC4A1 & $\begin{array}{l}\text { IMS-JST000828 } \\
\text { IMS-JST035905 } \\
\text { IMS-JST007939 }\end{array}$ & 0.274 & 0.218 & 0.373 \\
\hline $\begin{array}{l}\text { Solute carrier family } 6 \\
\text { (neurotransmitter } \\
\text { transporter, noradrenalin), } \\
\text { member } 2\end{array}$ & SLC6A2 & $\begin{array}{l}\text { IMS-JST113472 } \\
\text { IMS-JST113474 } \\
\text { IMS-JST065623 } \\
\text { IMS-JST014686 } \\
\text { IMS-JST014687 } \\
\text { IMS-JST014688 }\end{array}$ & 0.306 & 0.358 & 0.343 \\
\hline $\begin{array}{l}\text { Solute carrier family } 8 \text {, } \\
\text { member } 1 \\
\text { (sodium-calcium } \\
\text { exchanger-1) }\end{array}$ & SLC8A1 & $\begin{array}{l}\text { IMS-JST008552 } \\
\text { IMS-JST008552 } \\
\text { IMS-JST024796 } \\
\text { IMS-JST012941 }\end{array}$ & 0.608 & 0.284 & 0.449 \\
\hline Solute carrier family 9 & SLC9A3 & IMS-JST109880 & 0.255 & 0.984 & $0.005 *$ \\
\hline
\end{tabular}


(sodium/hydrogen

exchanger), isoform 3

\begin{tabular}{|c|c|c|c|c|c|}
\hline $\begin{array}{l}\text { Steroidogenic acute } \\
\text { regulatory protein }\end{array}$ & STAR & $\begin{array}{l}\text { IMS-JST005138 } \\
\text { IMS-JST005139 }\end{array}$ & $0.048 *$ & $0.02 *$ & 0.076 \\
\hline $\begin{array}{l}\text { Syntaxin binding } \\
\text { protein } 1\end{array}$ & STXBP1 & $\begin{array}{l}\text { IMS-JST111612 } \\
\text { IMS-JST037891 } \\
\text { IMS-JST012952 } \\
\text { IMS-JST012952 }\end{array}$ & $0.014 *$ & 0.014* & 0.51 \\
\hline Synuclein, alpha & SNCA & $\begin{array}{l}\text { IMS-JST131016 } \\
\text { IMS-JST131014 } \\
\text { IMS-JST130997 }\end{array}$ & 0.612 & 0.432 & 0.288 \\
\hline $\begin{array}{l}\text { Thyroid hormone } \\
\text { responsive SPOT14 } \\
\text { homolog }\end{array}$ & THRSP & rs545869 & 0.684 & 0.937 & 0.110 \\
\hline Ttk protein kinase & TTK & $\begin{array}{l}\text { IMS-JST049829 } \\
\text { IMS-JST157819 }\end{array}$ & 0.401 & 0.532 & 0.862 \\
\hline $\begin{array}{l}\text { TNF receptor } \\
\text { superfamily, member } 4\end{array}$ & TNFRSF4 & $\begin{array}{l}\text { IMS-JST053050 } \\
\text { IMS-JST053049 }\end{array}$ & 0.452 & 0.63 & $0.024 *$ \\
\hline $\begin{array}{l}\text { Vascular endothelial } \\
\text { growth factor } \mathrm{C}\end{array}$ & VEGFC & $\begin{array}{l}\text { IMS-JST130723 } \\
\text { IMS-JST130724 } \\
\text { IMS-JST109095 }\end{array}$ & 0.487 & 0.607 & 0.153 \\
\hline $\begin{array}{l}\text { Vesicle-associated } \\
\text { membrane protein } 3\end{array}$ & VAMP3 & $\begin{array}{l}\text { IMS-JST011175 } \\
\text { IMS-JST007813 }\end{array}$ & 0.088 & 0.063 & 0.123 \\
\hline Villin 2 & VIL2 & $\begin{array}{l}\text { IMS-JST110282 } \\
\text { IMS-JST088251 } \\
\text { IMS-JST088249 }\end{array}$ & 0.965 & 0.836 & 0.834 \\
\hline $\begin{array}{l}\text { WNK lysine deficient } \\
\text { protein kinase } 1\end{array}$ & PRKWNK1 & $\begin{array}{l}\text { rs1159744 } \\
\text { rs2158502 } \\
\text { rs } 718389\end{array}$ & 0.726 & 0.542 & 0.294 \\
\hline $\begin{array}{l}\text { WNK lysine deficient } \\
\text { protein kinase } 4\end{array}$ & PRKWNK4 & rs 324075 & 0.637 & 0.953 & 0.221 \\
\hline $\begin{array}{l}\text { a IMS-JST\# number from } \\
\text { number from dbSNP datab } \\
\text { b P values for overall distr } \\
\text { iterations using SNPAlyze } \\
\text { * Significant difference. }\end{array}$ & $\begin{array}{l}\text { e Japanese } \\
\text { (http://ww } \\
\text { tion of hap } \\
1 \text { Pro softw }\end{array}$ & $\begin{array}{l}\text { P database (http: } \\
\text { cbi.nlm.nih.gov/S } \\
\text { pes were calcula } \\
\text { (DYNACOM, M }\end{array}$ & $\begin{array}{l}\text { //snp.im } \\
\mathrm{NP} / \text { ). } \\
\text { ted by p } \\
\text { obara, }\end{array}$ & $\begin{array}{l}\text { l-tokyo. } \\
\text { nutatior } \\
\text { an). }\end{array}$ & jp/) or rs\# \\
\hline
\end{tabular}

IMS-JST025479 